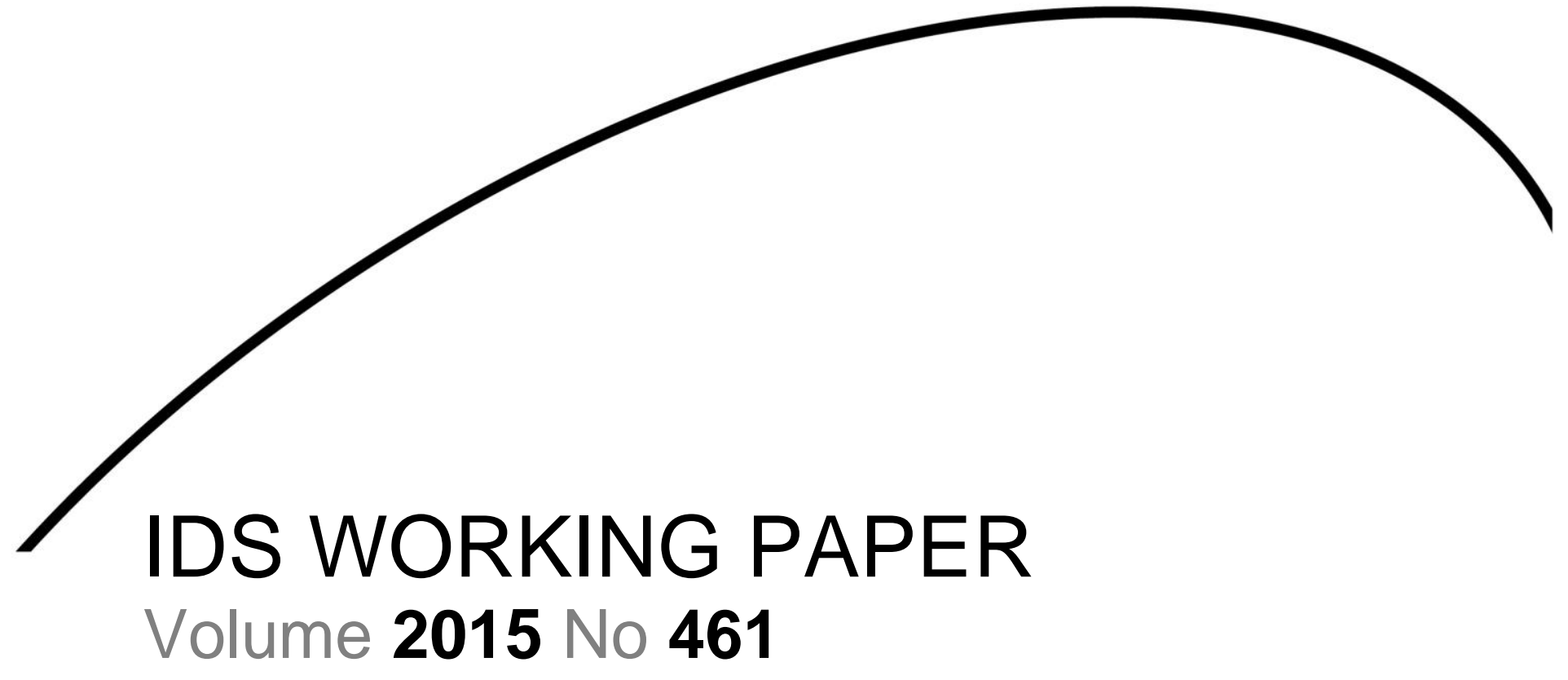

\title{
Food Riots and Food Rights: The Moral and Political Economy of Accountability for Hunger in Kenya
}

Celestine Musembi and Patta Scott-Villiers

July 2015 
Food Riots and Food Rights: the Moral and Political Economy of Accountability for Hunger in Kenya Celestine Musembi and Patta Scott-Villiers

IDS Working Paper 461

(C) Institute of Development Studies 2015

ISSN: 2040-0209 ISBN: 978-1-78118-251-2

A catalogue record for this publication is available from the British Library.

All rights reserved. Reproduction, copy, transmission, or translation of any part of this publication may be made only under the following conditions:

- with the prior permission of the publisher; or

- with a licence from the Copyright Licensing Agency Ltd., 90 Tottenham Court Road, London W1P 9HE, UK,

or from another national licensing agency; or

- under the terms set out below.

This publication is copyright, but may be reproduced by any method without fee for teaching or nonprofit purposes, but not for resale. Formal permission is required for all such uses, but normally will be granted immediately. For copying in any other circumstances, or for re-use in other publications, or for translation or adaptation, prior written permission must be obtained from the publisher and a fee may be payable.

Available from:

Communications and Engagement Unit, Institute of Development Studies, Brighton BN1 9RE, UK

Tel: +44 (0) 1273915637

E-mail: bookshop@ids.ac.uk

Web: www.ids.ac.uk/publications

IDS is a charitable company limited by guarantee and registered in England (No. 877338) 


\title{
Food Riots and Food Rights: The Moral and Political Economy of Accountability for Hunger in Kenya
}

\author{
Celestine Musembi and Patta Scott-Villiers
}

\section{Summary}

The green revolution and the global integration of food markets were supposed to relegate scarcity to the annals of history. So why did thousands of people in dozens of countries take to the streets when world food prices spiked in 2008 and 2011? Are food riots the surest route to securing the right to food in the twenty-first century? We know that historically, food riots marked moments of crisis in the adjustment to more market-oriented or capitalist food and economic systems. Food riots featured as part of a politics of provisions that helped hold public authorities to account for protecting people during price spikes or shortages. This research project interrogated this contemporary moment of historical rupture in the global food system through comparative analysis of Bangladesh, India, Kenya and Mozambique in the period 2007-12. This was a period of intensely volatile food prices as well as unusual levels of food-related popular mobilisation - unruly political events like riots but also more organised action like the Right to Food movement in India. During the global food crisis of 2007-8 alone, food riots (or subsistence protests) were reported in 30 countries. In many, including the four in our study, the food crisis triggered changes in domestic food security arrangements. Working with multiple methods and at different levels with media content, with activists and protesters, and with policy and political elites, this research asked: What motivated people to mobilise around food? And did popular mobilisation effect or influence such changes?

Keywords: food riots; food rights; popular mobilisation; accountability; moral economy; Kenya.

Celestine Musembi is a Senior Lecturer at the University of Nairobi School of Law, and a former Research Fellow at the Institute of Development Studies. She is a lawyer with interdisciplinary training and experience in legal anthropology. Her main areas of research interest include rights-based approaches to development, integrating participatory approaches into rights advocacy, access to justice at the local level, local implementation of international human rights standards, overlap between formal and informal legal regulation of land relations, and gender equality in property relations and in governance reforms.

Patta Scott-Villiers is a Research Fellow at the Institute of Development Studies and has worked for 25 years on issues of voice and power, primarily in the Horn and East Africa, but also in UK, Eastern Europe and other parts of the world. She specialises in citizen-led research in politically marginalised and fragile settings. Her current collaborations with citizen's groups in Uganda, Kenya, Palestine and Israel aim to support their efforts to change oppressive conditions; building informed action through co-operative research, public conversation and civil organising. Her research looks at how claims for social justice develop and are influenced through public conversation in a context of political society, moral economy and power. 


\section{Contents}

Summary, keyword and author notes 3

Acknowledgements $\quad 5$

Introduction $\quad 6$

$1 \quad$ Food price spikes, impact and the government's short term response $\quad 7$

1.1 Food price rises 8

$\begin{array}{ll}1.2 & \text { The impact of the price rises } \\ 1.3\end{array}$

$\begin{array}{lll}1.3 & \text { Assessing the government's short-term response } & 11\end{array}$

$\begin{array}{ll}1.4 & \text { Plunder or blunder? } \\ & 14\end{array}$

2 Popular mobilisation around food (2007 - 12) 14

$\begin{array}{ll}2.1 & \text { Food-related protest in Kenya } \\ & 14\end{array}$

$\begin{array}{ll}2.2 & \text { Forms of mobilisation } \\ & 17\end{array}$

$\begin{array}{ll}2.3 & \text { State response to popular mobilisation } \\ & 19\end{array}$

2.4 Institutionalised responsiveness? 21

2.5 Is there a social movement? 22

3 The Kenyan government's long-term policy measures 24

3.1 Intervention in maize marketing: the National Cereals and Produce Board 25

3.2 Ad hoc waiver of import duties on grain 27

$\begin{array}{lll}3.3 & \text { Production subsidies } & 28\end{array}$

$\begin{array}{lll}3.4 & \text { Food security policy } & 29\end{array}$

$\begin{array}{ll}3.5 \text { Social protection and relief } & 30\end{array}$

3.6 Exemption of essential food items from VAT 33

3.7 In summary: Is this accountability for hunger? 35

4 What Accounts for the Persistent Failure of Accountability for Hunger in Kenya? $\quad 35$

4.1 Political economy of food and agriculture policy in Kenya 35

4.2 Weak moral economy 36

4.3 The Right to Food has not taken root 38

4.4 Failure of electoral representation 42

5 Conclusion $\quad 44$

Annex 1 Government Officials and Activists Interviewed 46

Annex 2 Clustering of Participants in Focus Group Discussions 47

$\begin{array}{ll}\text { References } & 48\end{array}$

\section{Figures}

Figure 1.1 World and Kenya Maize Prices, Jan 2007-Dec 2012

Figure 1.2 Kenyan Maize Production, Consumption and Import 9

Tables

Table 4.1

Restrictive view of the right to food

39

Table 4.2

Expansive view of the right to food

40

Table 4.3

Cynical view of the right to food

40 


\section{Acknowledgements}

The authors wish to acknowledge all those who took part in the study: Mathare and lkutha residents who agreed to be part of the listening posts and focus group discussions, and government officials and activists who agreed to be interviewed. The authors also thank the research assistants without whom the study would not have been possible:

Bonface Omondi (in charge of media searches for events catalogue).

In Ikutha: Norah Mwende, Sharlet Martha Musingi, Stephen K. Mulatya, Eric Kitheka, Benjamin N. Kiema, Cynthia Muinde, Elizabeth Ngumii, Malombe Mulinge.

In Mathare: Anne Mbuthia, Stephen Irungu, Jason Waweru, Claris Akinyi. 


\section{Introduction}

In 2010 Kenya enacted a new constitution that brought into law a range of progressive economic and social rights including the legal entitlement of its citizens 'to be free from hunger, and to have adequate food of acceptable quality' (Republic of Kenya 2010). Hunger is widespread in Kenya and, despite the constitutional commitment, our study finds a persistent failure of accountability for hunger. Factors rooted in Kenya's history and political economy have dampened citizen expectations of the state, thwarted popular mobilisation and generated weak state responses. This raises a question of responsibility. In this paper, we explore the failure and efforts to overcome them, before considering how accountability for hunger can be made the norm.

The period from 2007 to 2012 was marked by high and volatile food prices worldwide. This triggered popular mobilisation in several countries, as well as varying responses by governments. Institutionalised accountability for hunger is generally weak, however. This is the case not only with respect to Kenya, but for most governments' responses to the food price surges of that period, according to the UN Special Rapporteur on the Right to Food. ${ }^{1}$ This paper is part of a four-country study that analyses these responses in terms of the degree to which they approximate accountability for hunger. The countries covered by the study are Bangladesh, India, Kenya and Mozambique. The central question addressed is: under what conditions do riots and 'right to food' campaigns make governments more accountable for hunger?

The premise of the study is that the convergence of a strong moral economy and sustained popular mobilisation in the right political conditions produces an accountable response to hunger. We use the term 'moral economy' to refer to a legitimate expectation, based on tradition, that authorities are obliged to take measures that cushion citizens against erosion of their most basic economic needs and efforts, most particularly in relation to food. We draw from E.P. Thompson's use of the term 'moral economy' to include the elements of a degree of social consensus as to what claims are legitimate, and a degree of state acceptance or at least concession (1971). The moral economy becomes visible in hard times, when people on low incomes move to protest against an immoral economy. When the fundamental norm of a right to be free from hunger is ruptured, citizens feel no compunction against disturbing the peace to make known their anger. Their call for a reinstatement of the moral economy is made with a sense of deep justification, even as they know that the political system from which this norm originated may have changed beyond recognition.

We use the term 'accountability for hunger' to mean:²

i) a mandate or binding obligation to ensure food security; ${ }^{3}$

ii) clarity of standards; ${ }^{4}$

iii) sanctions on public officials;

iv) a complaint or grievance system with provision of remedies for those affected by misuse of power or failures by public officials;

UN Special Rapporteur on the Right to Food (2014) Final Report: The Transformative Potential of the Right to Food, A/HRC/25/57. The responses 'did not include mechanisms for monitoring progress and accountability, or for ensuring that food producers and consumers participated in policymaking processes. They did not focus on the most vulnerable and they often failed to guarantee the transformation of support schemes into legal entitlements.' [para. 3].

$2 \quad$ Criteria adapted from Goetz and Jenkins (2005).

3 Clarity of mandate is established if there is a legal standard such as a constitutional guarantee of a right to food or a national food policy, coupled with clear identification of the responsible institution(s).

$4 \quad$ An example of clarity of standards is the spelling out of eligibility criteria for beneficiaries of food subsidies (e.g. in India's Public Distribution System). 
v) mechanisms for monitoring, internal as well as external, with

vi) space for citizen and civil society participation.

This paper relies on empirical data, interviews, media review, secondary data, academic literature and review of government policy documents. We collected the empirical data in two sites, urban and rural: Mathare, an informal settlement in Nairobi, and Ikutha market and its environs in Kitui county, in the south-eastern region of Kenya. Mathare has been a significant site of organising for the unga (maize meal) price protests that followed spikes in prices in 2009 and 2011. Ikutha was selected because it is among the areas in the country that are considered chronically food insecure. ${ }^{5}$ In spite of this it has not been the focus of government or non-governmental organisation (NGO) attention as a famine area due to its low political importance.

Our choice of research sites was also informed by a quest to find out why there were apparently no protests in hard-hit arid rural areas such as lkutha, in contrast to Mathare. However, as we discuss below, there is not a total absence of protest in rural areas. Rather, there have been incidents of localised protest, with a few peaks that have caught the attention of local language radio, with little to suggest possible build-up into large-scale protest.

The methodology of the study combines analysis of media reporting and review of policy, academic and legal documents with a series of focus group discussions (FGDs) and validation activities in the two sites, along with interviews with government officials and activists. The focus group participants were identified after conducting 'listening posts' in strategic locations in each site. A total of 14 FGDs were conducted, seven in each site. Validation workshops at the two sites followed preliminary analysis of the data.

This paper is divided into six sections, including this introduction. Section 2 details the impact of the food price spikes of 2009 and 2011 and evaluates the measures that the Kenyan government took in response to the crises. The third section discusses the popular mobilisation that took place in response to the crisis and the government's response to that, and it evaluates the performance of civil society in forming a 'right to food' movement. The fourth section examines long-term policy measures that relate directly or indirectly to food, assessing whether they amount to institutional accountability for hunger. The fifth section puts forward the key factors that have allowed failures in accountability for hunger to persist, followed by a brief concluding section.

\section{Food price spikes, impact and the government's short term response}

Over the years 2007-12, the prices of Kenya's main staple grain, maize, increased in a series of spikes. While the price rises may appear to be a reaction to spikes in global maize markets, closer examination shows that prices in Kenya rose more sharply and stayed higher for longer (Figure 1.1). This section looks at the history of the price rises year by year, noting key global and local influences. It ends by considering how people in different positions assessed government interventions during the crisis. 


\subsection{Food price rises}

Over the five-year period the prices of all foods rose, including prices for proteins (meat and beans) and cooking oil (Hossain and Green 2011; Lubaale 2013; Gatimu 2014). We focus on the maize price because maize is Kenya's most important food. Studies generally confirm that maize consumption accounts for more than half the total diet in the Eastern and Southern Africa region. ${ }^{6}$

Figure 1.1 World and Kenya Maize Prices, Jan 2007-Dec 2012

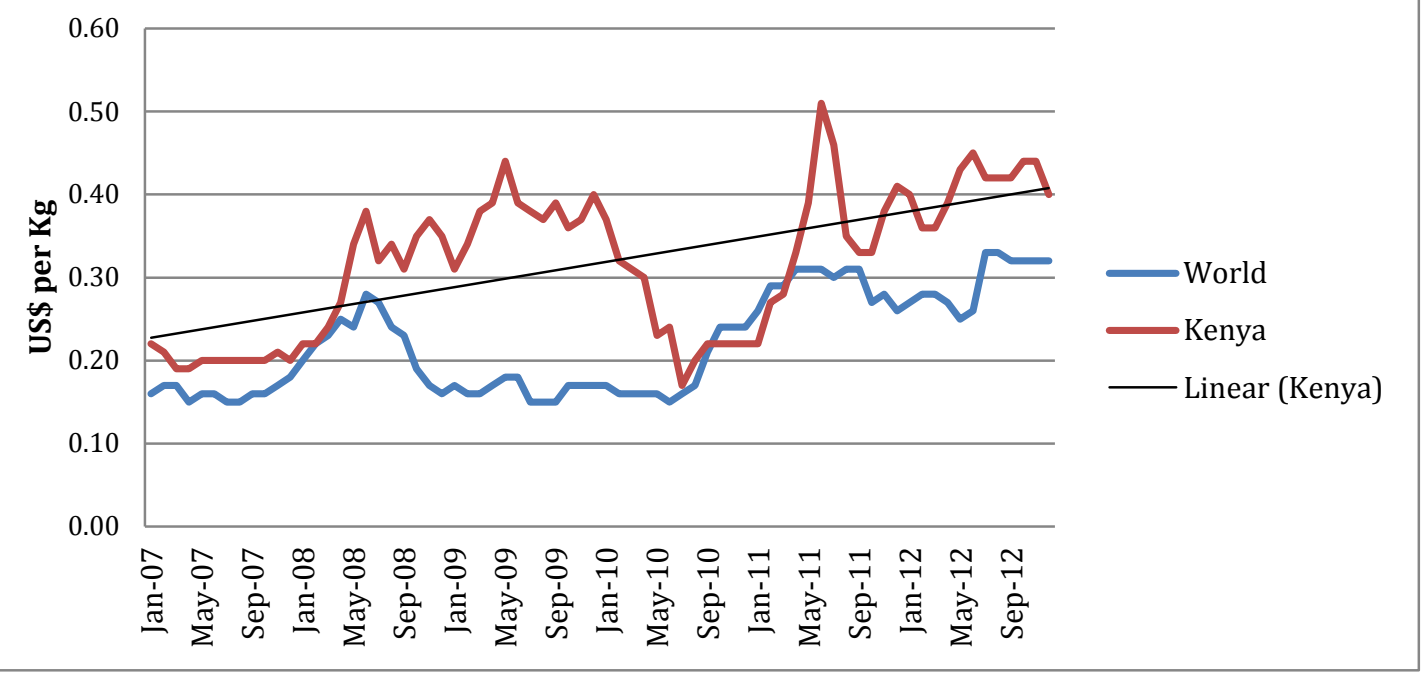

Source: FAO (2013a) Economic and Social Development Statistics Division. www.foodsecurityportal.org/api/countries/worldmaize-price

In December 2007, world prices of maize began to rise rapidly from $\$ 180$ per tonne, increasing by around 10 per cent each month to reach a peak in June 2008 at $\$ 270$ per tonne before falling back to $\$ 170$ in November (Figure 1.1). In Kenya, at the end of December 2007, violence and mass displacement of people followed the disputed election results and continued into February 2008. Losses of maize were estimated at 300,000 tonnes (around 10 per cent of Kenya's annual requirement). In addition farming in large parts of the country scaled back dramatically and the planted area for the crucial long rains decreased by 20 per cent (Short et al. 2013: 7; Fengler and Kiringai 2009: 11). On the world market costs of fertiliser and fuel rose rapidly, while in the region, poor rains throughout 2008 depressed production. The overall effect in Kenya was a deficit of some 1 million tonnes (Figure 1.2). 


\section{Figure 1.2 Kenyan Maize Production, Consumption and}

Import ('000 tonnes)

\begin{tabular}{|c|c|c|c|c|}
\hline & 2007 & 2008 & 2009 & 2010 \\
\hline Production & 2,925 & 2,367 & 2,439 & 3,222 \\
\hline Consumption & 3,265 & 3,381 & 3,501 & 3,626 \\
\hline Deficit & -340 & $-1,014$ & $-1,062$ & -404 \\
\hline Food aid (WFP) ${ }^{7}$ & 186 & 172 & 244 & 214 \\
\hline Imports & 254 & 288 & 1,600 & 349 \\
\hline Surplus/deficit & 100 & -554 & 782 & 159 \\
\hline
\end{tabular}

Source: Short et al. (2013) and World Food Programme (WFP) (2011).

Local deficits had historically been met by imports from Tanzania and Uganda, but these countries were also suffering the poor rains and high fuel prices, and official exports had been banned (Short et al. 2013). The Strategic Grain Reserve should have kicked in at this point, releasing reserve stocks held in the National Cereals and Produce Board (NCPB) stores into the market, but these were reported to have been exhausted (Höffler and Ochieng 2009: 29). In November 2008 the government eventually announced a scheme to increase supply: the NCPB would import maize and, with a subsidy made possible by aid from the Japanese government, sell to millers at below wholesale market prices, with the expectation that the millers would then sell the milled maize flour at a price below the prevailing retail market prices. ${ }^{8}$

NCPB imported 135,000 metric tonnes from South Africa by December, buying at around $\$ 400$ per tonne at Mombasa and selling to millers and traders at around \$209 (Jayne and Tschirley 2010: 8; Short et al. 2013: 11). Despite the subsidy, the consumer price of maize flour did not come down. PricewaterhouseCoopers estimated that at least 27 per cent of the subsidised maize went not to millers but to brokers who then sold on to the millers at a margin (Fengler and Kiringai 2010: 7). At least half of the maize allocations of the scheme's first phase went to only ten companies, including a transport company that had not been an active maize marketer up to that point. It is not clear that any vetting preceded the award of vouchers to companies deemed to be millers. In January 2009, the media reported substantial allegations of corruption in accessing the import facility and reported the diversion of duty free imports to Sudan (Ariga et al. 2010: 16). In February, the government abandoned the scheme. As the World Bank puts it, 'the Kenyan public lost an estimated 23.4 billion Kenya Shillings [KShs] [\$310 million] in subsidies and taxes foregone' (Fengler and Kiringai 2009: 13). The scheme joined the lexicon of Kenyan scams under the label 'the Maize Scandal'. 9

It was not until the end of January 2009 , more than a year after the post-election violence had kicked off the food price rises, that the government waived the 50 per cent import tariff

$7 \quad$ Estimate: total food aid to Kenya less the quantity supplied to refugee programme.

$8 \quad$ The Japanese government provided 940 million yen in 2009 and 630 million yen in 2010, which was used to purchase 42,000 tonnes of non-GMO maize, 90 per cent of which was sold to millers through NCPB at below market prices. The market price at the time was KSh3,500 per bag of maize, but millers got it at KSh2,700 per bag. The remaining 10 per cent was distributed to areas of the country with the highest vulnerability, through Kenya Red Cross and Catholic Relief Services. Interview, Food Security and Early Warning Programme, Ministry of Agriculture, 22 July 2013.

$9 \quad$ The scandal led to the sacking of the entire NCPB board of directors and 17 senior managers in early 2009 (Jayne and Tschirley 2010: 9), but no one was prosecuted and no further information was given to parliament or the Kenyan public about the scheme. 
for maize. Millers and traders moved quickly to make orders from South Africa. Within three weeks grain was flooding into the port at Mombasa (Jayne and Tschirley 2010: 9). The problem now was inland transportation, since the delayed lifting of the import duty meant that nearly a million tonnes arrived in the port in a single month. ${ }^{10}$

Even as global prices fell, local prices in Kenya continued to rise (Fengler and Kiringai 2009). By March, Kenyan wholesale prices had reached close to $\$ 400$ per tonne, a new record high and double the now plummeting international price. The 2009 long rains in April/May were once again disastrous. The drought led to reduced production of grains and a dramatic drop in hydro-electric power, necessitating oil imports which raised the cost of fuel, fertilisers and transport. By mid-2009 maize prices were once again double the global price and among the highest in Africa. In September 2009, after 21 months of crisis, Kenyan wholesale maize prices eventually began to fall as the impact of the imports began to be felt. The November 2009 short rains were abundant.

In 2010, a year of good harvests and relative political calm, prices fell back to 2007 levels. Food price inflation came down from a high of 27 per cent in December 2008 to a low of around 4 per cent in April 2010. Urban food prices stabilised and, as energy supplies became more reliable, urban employment improved (KFSSG 2010).

This period of relative calm was not to last, however. By February 2011 the maize price began to rise again, and by July 2011 it reached an unprecedented $\$ 510$ per metric tonne (FAO 2014, Demombynes and Kiringai 2011:3), 160 per cent of its June 2010 price and 70 per cent above the already high world market price (World Bank 2011: 3). Food production had once again been hit by poor rains and fell by 24 per cent on 2010 production levels. Rising global oil prices, contraction in Kenya's main Middle Eastern and European markets and an increasing current account deficit led to depreciation of the Kenyan shilling (Kiringai and Fengler 2011: vi). Imports of maize in 2011 were costing $\$ 299$ a metric tonne on the global market, but as much as $\$ 530$ on the Kenyan market (ibid.: 4). In July 2011, prices reached another all-time high, 70 per cent above world prices (ibid.: iii), and the government once again suspended the 50 per cent import tariff on maize for 'gazetted millers' for a period of six months in order to encourage maize imports. Imports increased supply but the prices remained stubbornly high and food inflation reached 24 per cent in August (ibid.: 2). As shortages grew, the NCPB released grain from the strategic reserve, distributing more than 80 per cent by August (World Bank 2011: 1).

In 2012 good rains boosted hydro-electricity supplies and with international oil prices also falling, fertiliser and transport costs fell. Food production increased by 16 per cent compared to 2011 (Randa and Gubbins 2013: 3). Inflation came down below 10 per cent, growth returned to 5 per cent and public debt fell. Uganda and Tanzania announced surpluses and lifted grain export bans. Food prices, although now stable, were still high at around $\$ 400$ per metric tonne; with maize almost double the global price (Kiringai et al. 2012: 2-8).

Over the five-year period, food prices rose inexorably, not always in line with global prices. In general Kenya has no staple food prices that show a long-run relationship with world markets (Minot 2011: 24). The other surprising fact is that prices did not always go down in years of high production. The implication is that food price rises are as much affected by domestic politics and policy as by other factors.

The port was capable of processing some 220,000 MT per month, but the road system could manage only around $150,000 \mathrm{MT}$. In competition with the annual imports of fertiliser, a large backlog developed in the port. These additional storage costs were also passed on to consumers (Jayne and Tschirley 2010: 7). 


\subsection{The impact of the price rises}

The price spikes have had a devastating impact for low-income Kenyans. FAO statistics indicate that 30.4 per cent of the Kenyan population was undernourished in the period 20102012 (FAO 2013b). In 2005, the national household survey calculated that nearly 17 million people were living under the $\$ 1.25$ poverty line (Randa and Gubbins 2013: 33). Kenya's own poverty lines - based on the cost of a basic food basket - averaged 47 per cent of the population, or nearly 20 million people, the majority of whom live in rural areas (ibid.: 33 ). Food inflation has been the main driver of overall inflation in Kenya in the last decade, particularly for the poor. At its height, in 2008, food inflation was 27 per cent. In 2011 poor people suffered overall inflation of 16 per cent compared to 8 per cent for high-income households (World Bank 2011: 2).

The empirical component of our study confirms previous studies showing that as the Kenyan food crisis deepened year on year, people on low incomes cut down on food. It was common for families and especially for women to be eating only one meal a day. They have been eating smaller portions, reducing the variety of food to mainly ugali (cooked maize meal) and kale and eating less nutritious foods (Hossain and Green 2011; Lubaale 2013; Gatimu 2014). ${ }^{11}$ People on the lowest incomes have been the hardest hit, because they have to spend the greater proportion of their incomes on food and transport, the two essential items with the highest levels of price inflation (Randa et al. 2012: 5-6). The World Bank estimates, for instance, that the number of families living in poverty in Kitui (one of the districts covered in this study) had increased between 2.7 and 5.7 per cent as a result of the food crisis (World Bank 2011: 7).

\subsection{Assessing the government's short-term response}

The government's short-term response to the food difficulties provoked by the price crisis provides an indicator of the moral economy as perceived by the political class. The response fell far short of an accountable system: there were no standards for responding, no clear criteria for eligibility, no mechanisms for enforcing standards and no sanctions for failure. The short-term measures taken by the Kenyan government in the period of the food price surges reflect momentary political anxiety rather than a commitment to institute long-term solutions for the differential impact on millions of people on low incomes. The crisis did not lead to famine, but it did contribute to persistent undernourishment, thus challenging any claims that citizens have a right to freedom from hunger. It suggests a weak moral economy in which people may go hungry, even though they will not be allowed to starve.

A senior policymaker, when interviewed, admitted that whereas Kenya has an efficient drought/famine response system, the country has no mechanism for responding to food crises of other kinds, such as those resulting from a spike in food prices or from chronic food shortage such as that experienced in lkutha. ${ }^{12}$ These do not fit within the 'disaster' profile, so when they have triggered a response from the political class at all, it has been short-lived, poorly targeted and poorly coordinated. Another policymaker corroborates this: 'The issue of subsidised food was tried but it was a total flop. It doesn't reach the very poor. We are still not well behaved. The rich people would still get access even to vouchers. ${ }^{13}$

Within government, the explanation for this state of affairs leans - not surprisingly - towards a narrative of 'blunder'. In one version of the narrative, bureaucrats blame politicians for

In Mathare, one frequently cited significant change was the relatively recent shift to small portions of ready-cooked roadside foods rather than home-cooked meals, to cut down on fuel costs as well as to match the flow of shrinking daily wages. In Ikutha the kadogo economy (re-packaging of basic food items such as flour, maize, sugar and cooking oil into ever-smaller portions) was cited as a recent significant change brought about by rising food prices.

Interview, National Drought Management Authority, Nairobi, 11 June 2013.

Interview, Social Protection Secretariat, Nairobi, 9 July 2013. 
acting on a populist impulse driven by the internal politics of the 'Grand Coalition'14 government that was in power:

The whole response was not very well thought-out. There were no structures in place. The whole response was partly political. It was meant to be short-term. There was immense political pressure to lower the price of unga. The former prime minister was given the task and he moved too fast before we could even discuss a road map on sustainability. ${ }^{15}$

In another version of the 'blunder' narrative, failure was blamed on the absence of mechanisms that the government could use to regulate the behaviour of the market actors at the centre of the drama, namely, the millers. The government 'blundered' by trusting the millers to pass on the maize subsidy to consumers of packaged unga:
Ah! Millers are businessmen. So parliament or the cabinet might just issue a declaration: "unga isifike mia" [maize meal should not get to one hundred shillings]. We simply tell the millers, "the government wants this". We deal with them through an association they have formed. The association gives us a guarantee that they will lower the price, but they then extract concessions [in return]. For instance, we will lower the price if you give us a duty-free facility. But really we have no way of enforcing what we agree with them; and most times the price change is minimal. There is no mechanism to ensure their compliance. We plead with them; we count on their goodwill. ${ }^{16}$

Implied in this version of the narrative is the argument that if there was any plunder at all it was orchestrated by the millers; the government only unwittingly facilitated it but by no means intended it.

Rights activists do not presume the government to have been so benign. The failure to establish a long-term institutionalised response represents such a protracted failure to learn from the past that it can only be seen as deliberate - designed to facilitate plunder.

Specifically, questions are raised repeatedly about the circumstances under which the Strategic Grain Reserve's stocks were sold off, so that there was none left to alleviate the crisis.

According to some observers, the scenario in 2009 was simply history repeating itself, when looked at in the context of the cycle of droughts and famines since 1965. In famines that occurred in 1965 and 1970-71, the Maize Marketing Board (the predecessor to the National Cereals and Produce Board) failed to maintain adequate stocks to deal with the maize shortage. Not only had the Board failed to maintain the requisite level of stocks, it was also party to the diversion of available supplies into the black market and the illegal export of maize (see Leys 1975: 106-7). When the Maize Marketing Board did act, well into the famine, its response was to set a producer price and to ban the export of maize. However, the producer price set was not attractive enough to stop a booming black market and illegal exports. The Kenyan National Farmers' Union, the large-scale producers' voice, then used this situation as the basis for pressuring for higher producer prices, which they achieved. The large-scale producers were the winners then, the grain traders were the winners in 2009.

\footnotetext{
14 Following the disputed elections of 2007 that plunged the country into conflict, a power-sharing deal created the office of prime minister to accommodate the declared runner-up, Mr Raila Odinga. The prime minister and president were to function as two principals in a Grand Coalition government, with cabinet positions also apportioned between the two factions. The arrangement proved a disaster; the Grand Coalition's internal wrangles and attempts to upstage one another were daily fare in the media.

Interview at Ministry of Agriculture, Nairobi, 22 July 2013.

Interview at Ministry of Agriculture, Nairobi, 22 July 2013.
} 
Government officials confirmed in 2013 that the Strategic Grain Reserve (SGR) had operating stocks below what would be adequate to cushion the country against food shortage for even one month:

Now the SGR has only 2.4 million bags of maize, and 45 metric tonnes of rice. This is very minimal. If we did have a crisis these stocks would only last three weeks. The diversification has not happened either [to include pulses, dried fish and powdered milk, as well as animal feed] but it is still in the plan. ${ }^{17}$

We wanted to have 8 million bags in the SGR (6 million in cash reserve, and 2 million in actual bags of maize). It's a target that we haven't reached yet. We only have the 2 million bags. Treasury did not release the rest. We are having difficulty in reaching 4 million bags. It's due to lack of funds... ${ }^{18}$

Rights activists in Nairobi who have researched the systematic marketisation of food shortages have come to the conclusion that the inadequate grain reserve,,$^{19}$ combined with the policy of an ad hoc waiver of import duties on food commodities are designed to facilitate plunder.

They point out that it is no coincidence that the period during which the import duty is lifted coincides with tightened restrictions on cross-border trade in grains. They claim that 'big traders' have inside information and get to know in advance of the announcement of a waiver of import duty. They also believe that these traders have the political muscle to put pressure on customs officials to activate non-tariff barriers in a way that is difficult to verify. ${ }^{20}$

According to the critics' view, there is a reason why government departments have successfully invested in a famine relief response mechanism but not in a long-term mechanism to deal with chronic hunger:

... within Special Programmes there is a "Response Unit", which is the most heavily funded. It is better funded than the National Drought Management Authority, which suggests more interest in these short-term responses than in long-term solutions. Reason? The "response" label draws in large amounts of money in a short span of time. This means that those involved can justify single-sourcing; they can bypass public procurement processes. They can source logistics such as transport from their wellconnected contacts. It is a well-oiled machine. So there is no interest in long-term engagement because long-term engagement does not make people rich. ${ }^{21}$

In short, activists believe that there is little interest in establishing institutions that work for the long term because 'we have a mafia that thrives on crisis. ${ }^{22}$

\footnotetext{
17 Interview at Ministry of Agriculture, Nairobi, 22 July 2013. At the time of the interview the Ministry of Agriculture was responsible for running the SGR. The SGR had been temporarily transferred to the Ministry of Special Programmes because the NCPB was facing legal problems and had its accounts frozen by a court order, which meant that it could not pay farmers. However, it soon became evident that the Ministry of Special Programmes did not have the capacity to manage the SGR, so it was transferred back to the Ministry of Agriculture in June 2013.

18 Interview at Ministry of Special Programmes, Nairobi, 3 July 2013.

19 Underfunding of grain reserves, it seems, is not unique to Kenya, and neither is the history of corruption in managing them (Murphy 2009). and Jayne (2010).

Activist, Nairobi, June 2014.

Activist, Nairobi, June 2014.
} 


\subsection{Plunder or blunder?}

While all parties agree that the responses to the food price crisis have been inadequate, if not scandalous, attribution of the cause varies. Government officials tend towards the narrative of blunder, with one department claiming failures in others, and overall a sense that the government does not lack goodwill in the fight against hunger, but leadership and resources. Its critics, including some within government itself, call it plunder. Activists tend to believe that the failures are a consequence of a kleptocratic political economy, in which political leaders, members of the civil service and large producers and traders excel in moralistic rhetoric while colluding to make money out of both prices rises and government mechanisms aimed at alleviating food stress. They point to a systematic absence of accountability to ordinary Kenyans for the right to adequate and decent food - despite the lofty claims of the constitution. They also point to a weak response from citizens, suggesting that a moral economy of legitimate access to decent food, if it exists at all, has a weak hold on the imaginations and actions of Kenya's government, traders and citizens alike.

\section{Popular mobilisation around food (2007-12)}

Protest has taken several forms: public discussion, the seizing of 'state spaces', street demonstrations in the capital, petitions, court action, and sporadic localised agitation. In this section we enumerate some of the most visible popular mobilisations and consider what they tell us about public perceptions of the right to food and a fair economy. We consider governmental response to protest and ask whether it indicates a move towards systematic accountability for freedom from hunger.

\subsection{Food-related protest in Kenya}

The high cost of living, specifically the cost of basic food commodities, featured prominently in the protests that took place in Kenya between 2007 and 2012. Strikes by public school teachers may have been triggered by the government's reneging on a pay deal negotiated in 1997, but the messages of the protest repeatedly cited the high cost of living, juxtaposed with a detailed breakdown of a typical teacher's monthly pay to back up their case. The high cost of living also featured prominently in strikes by medical staff at public hospitals. However, the most notable protests related specifically to the cost of the staple food unga.

The protests have now come to be identified as the 'Unga Revolution', led primarily by Bunge la Mwananchi. ${ }^{23}$ Although the name has now become something of an institution, it first appeared in the national media as the chant of a diverse gathering of workers heckling the labour minister reading the president's speech at the official Labour Day celebrations on 1 May 2009 (see Barasa 2009). The workers were unimpressed with the announcement of an 18 per cent rise in the minimum wage only for the lowest paid category. Chants of 'unga!' 'stima!' (electricity!) and 'maisha ngumu! (life is hard!) took over. The minister was forced to cut short and eventually abandon the reading. The workers then proceeded to stage a

Bunge la Mwananchi [literally, the ordinary person's parliament] was founded in 1990. It started as a ragtag movement discussing inter-religious harmony between Christians and Muslims, following several incidents of conflict, then broadened out to constitutional reform. At a time when few dared to speak out, Bunge dared to identify its mission as providing a public platform where ordinary citizens could discuss constitutional reform to address social justice issues affecting them. Martin Shikuku, an outspoken critic of the Kenyatta and Moi governments and a veteran independenceera politician, was actively involved in its foundation. Consolidation of a leadership structure within the movement only came after 2002. There is a bunge [parliament] in every ward, some very active and others not so, culminating in a national bunge. The Unga revolution drew its energy from bunge chapters in Nairobi's informal settlements. 
walkout before the national anthem was played to mark the premature end of the celebrations.

Away from the eyes of the national media local chapters of Bunge la Mwananchi (Bunge) had been hard at work organising protests over the rising cost of living since $2005 .{ }^{24}$ They were doing this both in their vibrant weekly outdoor debates in Nairobi's Jeevanjee Gardens, a public park, and in campaigns within low-income neighbourhoods. On 31 May 2008 Bunge had organised a procession from Jeevanjee Gardens to culminate in a 'social forum' in a lowincome neighbourhood in the Eastlands area of Nairobi to deliberate on the rising cost of living. Police broke up the procession and arrested leaders. Undeterred, Bunge continued to organise a series of protests that did not draw much media attention, until they twinned the issue of the cost of living with the issue of suppression of press freedom. This culminated in a high-profile infiltration and disruption of the Jamhuri (independence) Day celebrations in December 2008. Several Bunge members and journalists were arrested and assaulted by the Presidential Guard, giving immense publicity to the protest. ${ }^{25}$

With the exception of teachers' and medical staff strikes, the year 2010 records little by way of food-related protest. In that year, a national referendum on the adoption of a new constitution absorbed the national media. The Unga Revolution returned with a bang in 2011, dominating the Labour Day celebrations once more. A large banner with 'UNGA' prominently scrawled across it was unfurled right under the platform on which the dignitaries were seated. Protesters staged a mock march-past parade before they were hurriedly bundled out, and persistent heckling greeted all the speeches, including that of the Secretary-General of the Central Organization of Trade Unions (COTU). Clearly, even away from national media attention, the level of disillusionment with official responses since the 2009 Labour Day protest had kept pace with the cost of living (see Mutambo 2011).

Two weeks prior, Bunge had supported a street protest within the city centre led by the Consumers' Federation of Kenya (COFEK) against the government's announcement of a steep increase in the price of fuel, which would affect food prices. ${ }^{26}$ Synchronised acts of protest between COFEK and Bunge kept the issue in the media, eclipsing the 1 June Madaraka Day celebrations. ${ }^{27}$ On 30 May 2011 COFEK filed a law suit against the government offices concerned with regulation of the energy sector and on 31 May the Unga Revolution took over Harambee Avenue, the location of the Office of the President and the then Office of the Prime Minister, temporarily renaming it Unga Avenue. An attempt to repeat the Harambee Avenue take-over on 7 July (the unofficial commemoration of the 'heroes' who fought against the regime of President Daniel Arap Moi for the re-introduction of multiparty democracy in the early 1990s) was thwarted by heavy police deployment.

The next time food-related protest received national media attention was June $2013 .^{28}$ The protests were against a proposed revision of the Value Added Tax (VAT) Act to apply the full rate of VAT (16 per cent) on products (including basic food commodities) which had previously been either zero-rated or exempted. ${ }^{29}$ Food items, including packaged unga, had 
enjoyed zero-rated status since $2003 / 4$. This date is significant because it marked the early days of the then highly popular government that ended the 40-year reign of the KANU oneparty state. This was the government's second effort at VAT reform, having withdrawn the bill from parliament in 2012 following criticism from some members of parliament and civil society groups. The National Taxpayers' Association (NTA), for instance, had criticised the bill for deliberately omitting to spell out which items would receive a zero rating, adopting a case-by-case approach that is prone to abuse:

\begin{abstract}
The current version of the VAT bill has not specifically identified the zero-rated commodities. Instead, it has simply made provision for this to be done on a case-bycase basis. It would be dependent on the sympathies of whoever happened to be the minister for finance at any point in time. We want this bill revised before it is passed so that we know expressly. Why this vagueness with respect to VAT, yet finance bills are always so detailed? If you look at all the finance bills presented in parliament after the budget... you see that the government will go to the extent of identifying specific small items like "we will charge excise duty on malt and malt beer but not on spirits". It's very detailed, but they don't do it for food. Just state clearly "maize", or "unga"; that's not so difficult. ${ }^{30}$
\end{abstract}

The NTA was also opposed to the manner in which the government attempted to pass the bill without proper scrutiny and public debate, employing the 'guillotine' system whereby several finance bills are clustered together and passed through parliament as one batch.

A coalition of organisations led protest rallies for three days (24-26 June 2013) following the budget speech in which the government announced its intention to re-introduce the VAT bill. This was followed on 2 July 2013 by a protest march led by COFEK, timed to coincide with the first reading of the bill in parliament. Protesters marched from Freedom Corner ${ }^{31}$ to the Treasury building and National Assembly, bearing lumps of ugali (cooked unga) and a petition calling for the resignation of the cabinet secretary for finance (see Mutambo and Ngirachu 2013). This was followed on 7 July 2013 by a procession from Kibera, one of the largest informal settlements, culminating in a rally at the Kamukunji grounds, whose symbolic significance we explain below. The issue of high food prices and the high cost of living continued to feature in a series of protests that took place in $2013 .{ }^{32}$

lindex.html; J. Anyanzwa and M. Kamau, 'Tax shocker in cabinet secretary Henry Rotich's budget in his bid to fund new rail system', EA Standard, 15 June 2013, www.standardmedia.co.ke/?articlelD=2000086001\&story title=tax-shocker-incabinet-secretary-henry-rotich-s-budget-in-his-bid-to-fund-new-rail-system\&pageNo=1; A. Mutambo, 'Activists to protest against "unga" taxes', Daily Nation, 16 June 2013, www.nation.co.ke/News/Activists-to-hold-Unga-tax-demo/-

/1056/1885152/-/mklhgv/-/index.html and K. Njoroge, 'Groups set for rallies against VAT on food', Daily Nation, 24 June 2013, www.nation.co.ke/News/Groups-set-for-rallies-against-VAT-on-food/-/1056/1893408/-/e5qt3ez/-/index.html. Coverage on TV: NTV 25 June 2011, https://www.youtube.com/watch?v=0-m37zxGu5c.

30 Interview, National Taxpayers' Association, Nairobi, 3 June 2013.

31 The choice of Freedom Corner is symbolic. A section of Uhuru Park was named 'Freedom Corner' by the Nobel Laureate Wangari Mathai during the struggle that she and others led against the excesses of the Moi regime in the late 1980s and early 1990s.

32 The most prominent of these protests was the 'M-Pigs' protest. In 2013, MPs proposed a salary rise for themselves. It was the third in as many years for elected representatives who are among the highest paid in the world. The move generated wild protests in Nairobi with the 'M-Pigs' demos led by a coalition of activist leaders including leaders and members of Bunge la Wanachi. After days of gleeful television coverage of chanting protesters and pigs' blood splashed on the steps of the parliament building, the leaders appeared to back down from the headline salary rises they were demanding. The Salaries and Remuneration Commission re-considered. Some weeks later it announced a new decision. Salaries would not rise. Victory for the protesters? No. While base salary, already 150 times the average income of a slum-dweller, rose only a modest amount, the new scale of allowances meant, in effect, an even bigger package of remuneration than had been on the table a few weeks before. See J. Macharia 'Kenyan MPs take first pay cut, but allowances mount' 12 June 2013, www.reuters.com/article/2013/06/12/us-kenya-parliament-payidUSBRE95B0Y220130612 


\subsection{Forms of mobilisation}

A perusal of the Kenyan newspapers and news channels gives the impression that there are relatively few full-scale riots over the cost of living. The most visible form of protest is the organised demonstration, but this is only the tip of the iceberg. In our study we found numerous instances of citizen protest indicating a breached moral economy.

\subsubsection{Public debate}

Whereas many mobilising groups focused on policy research and lobbying, Bunge la Mwananchi has directed its mobilisation activities at promoting public discussion. Through a weekly forum in Jeevanjee Gardens and other town centres, Bunge volunteers presented citizens with illustrations of the volatility and steep rise of unga prices since 2002, and facilitated debates. People compared the situation to the relative stability in food prices that they had felt during the era of Kenya's one-party state under Moi and his KANU party. During Moi's 24-year reign, the price of unga had risen by KSh24 (a rate of one shilling per year); yet within three years of Moi's departure (2005), the price had shot from KSh27 to KSh47 (more than six times the previous rate). Counter-intuitively for a movement that had started in 1990 in bitter opposition to the one-party state, its leaders were making a moral economy argument that faulted the post-2002 governments that claimed to be democratic. They pointed out that even a dictatorship kept its bargain with the poor as far as affordability of basic food commodities is concerned. The contrast achieved the desired effect of stirring up public outrage and collective action to protest.

\subsubsection{Grabbing state spaces}

A second form of mobilisation has emerged from a number of energetic groups with a talent for publicity. It is a trend 'hijacking' national celebrations for the dual purpose of gaining an audience with high-ranking officials and media attention. This strategy was successfully employed during the Jamhuri Day celebrations in December 2008, all the Labour Days since 2009 (with the exception of 2010), and Madaraka Day in 2011. The activists would, in all probability, consider their action a legitimate reclaiming of national forums that have been turned into exclusive 'state spaces'.

Alongside this 'hijacking' of official functions, activists have maintained a two-decade long tradition of observing Saba Saba Day (7 July). The phrase simply refers to the seventh day of the seventh month. Saba Saba Day commemorates 7 July 1990, the day on which the Moi government cracked down heavily on proponents of multiparty democracy after a rally at the Kamukunji grounds, arresting and detaining all of the movement's leaders. The price of food was the focus of the 2011 Saba Saba rally in Kamukunji, while in 2013 the focus was on 'unga tax' (the VAT extension proposal outlined above). Speakers at both events exploited to full effect the historical link between the securing of 'political freedom' in the 1990s and the pursuit of the 'social and economic freedoms' promised by the 2010 constitution. ${ }^{33}$ Care was taken in every protest to involve key figures identified with earlier struggles. Paul Muite, a leader of the original Saba Saba days makes a prominent appearance in the unga protests, as does Professor Yash P. Ghai of the struggles for a new constitution in the early 2000s. This aims to legitimise the protest in the eyes of the public. 


\subsubsection{Street demonstrations}

A third form of mobilisation has been street demonstrations, particularly in the Nairobi city centre. The often-theatrical demonstrations have attracted much media attention, especially when they have been accompanied by confrontation with police and some arrests and assaults. What the media does not capture, however, is the intense behind-the-scenes mobilisation and awareness-raising in low-income neighbourhoods that precedes the street event. It is on account of this less visible mobilisation that one encounters some very wellinformed analysis on food politics in poor neighbourhoods such as Mathare.

Petitions are not uncommon in association with demonstrations or marches. They involve the background work of getting enough signatures, then a high-profile march to the relevant office to present the petition. The VAT protests, for instance, received sustained media coverage in June/July 2013 for the protests that were organised to coincide with parliamentary debate on the VAT bill. However, as early as June 2012 the campaign had collected more than 10,000 signatures on their petition to retain the exemptions and the zerorated status of basic commodities. In most instances police block the protesters from accessing the official to whom they intended to present the petition. In a rare gesture, one of the Unga protests (31 May 2011) saw the prime minister come out onto the street to personally receive the petition, and then plead with the protesters to give him time to exercise his 'right of reply'. ${ }^{34}$ In all probability such a response was only made possible by the internal rivalry of the Grand Coalition government.

\subsubsection{Court action}

The Consumers' Federation of Kenya (COFEK) is the only group on record as having taken court action to compel the government to invest in measures to bring down the cost of living, by reforming its regulation of the energy sector. COFEK sued the Energy Regulatory Commission, the National Oil Corporation, and the ministers in charge of finance and energy. ${ }^{35}$ At the court's initiative, the oil marketing companies were added as interested parties (Total, Shell and OiLibya). COFEK wanted the court to issue a declaration to the effect that the government agencies' failure to stabilise and bring down fuel prices had the effect of raising the cost of food, thereby breaching Article 43 of the constitution which guarantees Kenyans the right to be free from hunger, and the right to adequate food of acceptable quality. COFEK asked the court to issue orders compelling these agencies to take the necessary administrative and regulatory measures to reduce the high food prices and avert the looming food crisis.

The petition was only heard in court over a year later (July 2012), largely due to the failure by COFEK's lawyer to file submissions within the agreed timeframe and to appear in court on dates agreed. The delay strengthened the government agencies' assertion that the petition had been overtaken by intervening events: the rains had come bringing a relative reduction in food prices, and fuel prices had fallen slightly below the May 2011 levels, partly on account of a government reduction of excise duty on diesel and kerosene. It is clear from reading the judgement that COFEK's petition was poorly substantiated; no evidence was presented of a violation of Kenyans' right to food; there was no impact data; no outlining of the measures the government had taken so far or any illustration of how they failed to meet the constitutional standard of ensuring progressive realisation of social and economic rights. ${ }^{36}$

\footnotetext{
34 See www.youtube.com/watch?v=GaTG8CgFKyU [Citizen TV, uploaded 19 June 2011, but it must have aired on 31 May, because of the message 'no Unga, no Madaraka Day']. See also coverage on NTV: www.youtube.com/watch?v=CZe5tX28cHk.

35 Consumers' Federation of Kenya (COFEK) v. the Attorney-General, Minister for Energy, Minister for Finance, Energy Regulatory Commission and National Oil Corporation, Petition No.88 of 2011 (High Court, Milimani), available at www.kenyalaw.org.

$36 \quad$ The judge laments: 'Other than the statements set out above, the petitioner has placed nothing before the court that can assist the court in determining the alleged failures by the respondents.' The judge admonishes COFEK for not taking
} 
There is no record of COFEK having tried to compel the government agencies in question to allow COFEK access to the records that would enable them to substantiate their petition. In essence the much-touted court action was a wasted opportunity.

\subsubsection{Riot}

Besides the more organised forms of mobilisation discussed so far, there are sporadic and localised riots that have received little media attention and yet indicate that breaches in the moral economy are more common that hitherto recognised. We encountered these in our field research, both in Mathare and Ikutha. In Mathare spontaneous skirmishes were witnessed repeatedly at the depots where the urban poor tried to buy the government's much-touted subsidised unga. They were also witnessed during food distribution to Mathare's internally displaced persons, who were still homeless after the 2007-8 postelection violence. The skirmishes were triggered by alleged manipulation of the beneficiaries' list by local administrators. ${ }^{37}$ They went unreported in the national media.

In Ikutha we became aware of at least three protests against local administrators in the distribution of relief food. The first two were directed at the district commissioner for his personal involvement in hoarding and then re-selling relief food. In one incident the protesters, with the backing of a local councillor, succeeded in preventing a truck loaded with relief food from leaving the commissioner's compound, and forcing instant distribution of food stockpiled in a government warehouse. ${ }^{38}$ The third was even more localised, directed at an assistant chief for allegedly stashing relief food away in a store room in his office. His defence was that he was storing it temporarily for some beneficiaries who had not attended the public distribution. Protesters made calls to a local language radio station that captured the drama as they forced the store open and distributed the food. ${ }^{39}$

\subsection{State response to popular mobilisation}

The state's responses have varied from repression to appeasement, including a showing of solidarity by individual politicians, to incidences of institutionalised responsiveness.

\subsubsection{Repression}

Repression has taken the form of blocking off access to government offices to which protesters had announced their intention to deliver petitions. This has led to violent confrontation between the police and protesters, as was the case with the Unga protests of 2011. These violent confrontations were then followed by arrests but not by any formal charges. Denial of (or delay in offering) medical treatment to those injured by police is also a common occurrence, confirming that the purpose is intimidation and deterrence of popular mobilisation. Threats to movement leaders are also part of the repressive response. ${ }^{40}$ One of the community activists in Mathare found herself confronted in her police cell by the three most senior police officers in the district, all from her ethnic group, deriding her for having been brainwashed by an 'enemy' tribe: 'Don't you know that "we" are now in power? What are you protesting about?'41

seriously and giving insufficient attention to the critical issue it was asking the court to decide. COFEK judgement, p 8, 10.

$37 \quad$ Focus group discussion with internally displaced recipients of food aid, Mathare, 10 June 2013.

38 Focus group discussion with small-scale market traders, Ikutha, 29 June 2013; Interview with Hussein Mwandia, member of county assembly, Ikutha ward, Kitui, 26 July 2013.

$39 \quad$ Interview with Hussein Mwandia, member of county assembly, Ikutha ward, Kitui, 26 July 2013; interview with Francis Mutinda Sua, chief, Simisi location, Ikutha district, 26 June 2013.

40 See 'Consumer Federation chief warned over food protests', Daily Nation, 26 April 2011, www.nation.co.ke/News//1056/1150446/-/10xunrnz/-/index.html

Focus group discussion with community activists, Mathare, 10 June 2013. 


\subsubsection{Appeasement}

On the eve of the COFEK-led protest against the fuel prices and their effects on the prices of food, the minister for finance announced a reduction in excise duty for kerosene and diesel by 30 and 20 per cent respectively. This translated into a reduction in the price of KSh2.16 and KSh2.06 respectively (\$0.024). Protesters dismissed this as insignificant because a more significant tax - the fuel levy - was left untouched, and this accounts for 45 and 55 per cent of pump prices of kerosene and diesel respectively (see Njagih 2011).

The other incidence of appeasement came when the government made subsidised unga available in designated outlets in poor urban neighbourhoods between December 2008 and March 2009. This measure failed spectacularly: the unga proved elusive, and traders, rather than poor households, became its greatest beneficiaries, bulk-buying for re-sale at the higher market price. ${ }^{42}$ Not much reflection followed the failure because 'somehow people survived and life continued. ${ }^{43}$ However, the disillusionment it generated still continues to reverberate in the urban slums:

Have you ever seen the government respond to anything beyond just the day of the protest? For example at Unga revolution, the PM promised affordable unga, but that only lasted a few days. Is there anything that moves the government to take more serious action $?^{44}$

One policymaker, when asked what he would do in the face of persistent protest about food prices, said, 'we would quickly come up with something if Kibera was burning. ${ }^{45}$ It indicates that the response to protest is mostly about quelling the noise. It has little to do with systematic relief, or transformation of the pricing system - and more to do with being seen to respond.

\subsubsection{Solidarity or populist opportunism?}

There are several incidences of individual politicians lending support or expressing agreement with the protests. The campaign can boast two presidential pledges to take measures to make food affordable, but these are characteristically not backed by anything in written actionable form. ${ }^{46}$ The prime minister's plea to the unga protesters for time to reply resulted in no action, prompting them back on to the streets on Saba Saba day and thereafter. Then there is Mike 'Sonko' Mbuvi, the maverick MP for Makadara at the time of the 2011 protests, now senator for Nairobi. During the unga protests of 31 May 2011:

... Sonko came; he wanted to give out money, but we agreed that no one would take the money and if anyone did, they would be beaten up. We chased him down "Unga Avenue" (that is the name we had given to Harambee Avenue).

We wanted food costs to come down; that is what we had gone to protest; we didn't want his money. And we knew he had been sent so that he could keep us quiet. So we told him to take the money back to whomever had sent him with it. Had we taken that

\footnotetext{
42 Focus group discussion with community activists, Mathare, 10 June 2013. Government officials acknowledged that this intervention was ill-conceived and hurriedly implemented.

Interview, National Drought Management Authority, 11 June 2013.

Focus group discussion with young people, Mathare, 10 June 2013.

The official distinguished between the 'Kibera burning' type of protest, and the 't-shirt wearing' type of protest. The latter can be ignored without consequence. [Official's name withheld, Nairobi, July 2013]

46 See 'Kibaki pledges action on food prices', Daily Nation, 21 April 2011, www.nation.co.ke/news/Kibaki-pledges-actionon-food-prices/-/1056/1148994/-/mfgfus/-/index.html; F. Olick, 'We will lower cost of food, President Uhuru Kenyatta assures Kenyans', EA Standard, 21 June 2013, www.standardmedia.co.ke/?articlelD=2000086431\&story title=Kenyawe-will-lower-cost-of-food-uhuru-assures-kenyans.
} 
money, we would have lost the focus for which we had come. We would have started to fight over the money and forgotten why we were there. It was a way to divide us.

Sonko just wanted to be popular. He had come with his own media people. This initiative was for the Kenyan people. MPs had seen what was happening, but they had done nothing. We didn't go for this protest wanting to get involved with any politics. ${ }^{47}$

Stung by this rebuff, Sonko led an unga protest of his own a few days later, flanked by his supporters carrying packets of unga on their heads. The expensive commodity liberally powdered his face and neck. The incongruity of his bejewelled hand with five large gold rings clasping a torn packet of unga was lost both on him and on his supporters. ${ }^{48}$

COFEK-led protesters unable to access the Treasury building found an ally in Ababu Namwamba, an MP who promised to pass on their petition to the Speaker of the House, describing the protesters as 'heroes'. That afternoon, he moved a motion in parliament to debate what the government was doing or could do to cushion poor Kenyans against the increase in food prices brought about by high fuel prices. The debate, however, ended up being dominated by accusations and counter-accusations of corruption in the energy sector. ${ }^{49}$ The parliamentary committee concerned with matters of energy called a press conference demanding that the energy minister take action to dismantle the cartels that were making fuel unaffordable or face 'radical restructuring' of his ministry. The committee also threatened to disband the Energy Regulatory Commission, alluding to collusion between the commission and fuel cartels (see Shiundu 2011).

In Ikutha a locally elected representative has established a reputation for solidarity with protests over malpractices in relief food distribution in the famine-prone district. He was associated with all three localised protests that we encountered, which yielded immediate benefits to the residents but it cost him in terms of relations with the local (appointed, not elected) administrators. The Ikutha electorate had the final word however, when they reelected him in March 2013 to the Kitui county assembly.

\subsection{Institutionalised responsiveness?}

Two incidents show parliamentarians leaning towards institutionalisation of responsiveness (i.e. beyond simply the individual sympathetic MP). The first concerns the VAT Act (2013), and the second the enactment of the Price Control (Essential Goods) Act (2011). ${ }^{50}$

A number of MPs had already opted in late 2012 to side with the protesters opposed to application of the full rate of VAT on basic food commodities (see Gitonga 2012). A looming general election might have had something to do with this move:

There was a lot of TV and media coverage on the VAT bill. Some member of parliament appearing there defending the ordinary people's interest was something from which they could gain a lot of mileage. ${ }^{51}$ la Mwananchi, 3 June 2013. Interestingly, we were unable to find national media reports of this confrontation between Sonko and the unga protesters.

48 See Kenya Broadcasting Corporation (KBC) clip: www.youtube.com/watch?v=J64zI3vQpG4

49 See 'MPs lost a golden chance to show solidarity with hungry Kenyans', Daily Nation, 20 April 2011 , www.nation.co.ke/oped/Letters/-/440806/1148162/-/9teqc6/-/index.html 
The campaign for zero-rating food items continued to attract MPs' support even after the general elections, notably MPs from the Jubilee coalition of parties that got into power, since lowering food prices had been one of their campaign promises.

During his inauguration speech, Deputy President William Ruto made an impassioned declaration of the new government's commitment to reducing food prices for the poor. "Wale ma-sufferer wanataka kujua wakienda kwa kiosk ni lini bei ya unga itatoka shilingi mia moja ifike shilingi sitini (The long-suffering man wants to know when the price of a packet of maize flour at the kiosk will come down from 100 to 60 shillings)..."52

The president reiterated this promise at the National Prayer Breakfast, just a week after the VAT bill had been tabled in parliament. ${ }^{53}$ However, keeping this promise conflicted with other goals such as meeting Kenyan Revenue Authority targets. That the VAT Act was eventually enacted with exemptions for some essential food items, including unga suggests that there was significant pressure to keep (or at least be seen to be keeping) the campaign promise. It was of political significance that this was the first budget for the newly elected 'Jubilee' government. Keen for it to be perceived as a 'pro-poor' budget, it is not surprising that a large number of Jubilee MPs supported the 'anti-unga tax' campaign. ${ }^{54}$

The second instance concerns price controls. In June 2010, in an apparently hasty response to the various cost of living-related protests in 2008 and 2009, parliament debated and passed a bill bringing several essential commodities under a price control regime. Coming just two months before the national referendum on adopting a new constitution, the gesture was viewed with suspicion in business quarters. Economist think-tanks described it as illthought through..$^{55}$ Their pressure resulted in President Kibaki's refusal to assent to the bill, citing Kenya's obligations under international and regional trade treaties. In June 2011 a parliamentary select committee on the cost of living was set up, whose work eventually led to a revised version of the bill. This, the president agreed to assent to, and it was enacted into law in September 2011.

The Act is very brief however. It simply gives power to the responsible minister to declare, through a notice in the official Gazette, any goods to be essential commodities and thereby set a maximum price for it 'in consultation with the industry'. Offences and penalties are provided for contravention of the law, but no institutional mechanism is legislated for its enforcement. Rather, the minister is simply given powers to enact regulations 'for the better carrying out of the intent and purposes of this Act.' It is not clear which ministerial docket has the mandate to implement this law: is it under trade/commerce, or is it under social protection? There is no provision for compelling the minister to enact the regulations or explain his choice not to. It is easy to see that what started out as a parliamentary initiative really ended up in the complete control of the executive and the business sector. This piece of legislation has all the makings of a dead law. Activists have not engaged with it at all.

\subsection{Is there a social movement?}

Our survey of protests indicates that mobilisation and engagement with government on social and economic rights tends to be episodic rather than sustained. As such, Kenya cannot

\footnotetext{
52 See 'Protests, strike threats, greet Uhuru Budget', Sunday Nation, 14 June 2013.

53 See F. Olick, 'We will lower cost of food, President Uhuru Kenyatta assures Kenyans', The Standard, 20 June 2013.

54 On one of the days of debate on the VAT bill, however, parliamentary proceedings nearly came to a premature end because MPs whose car grants had not been released by the Treasury threatened to halt all business unless these were paid before the recess. This sent the message that MPs' apparent responsiveness and empathy could be cast aside when their own interests were at stake. See 'MPs Uproar over Car Grants' Kenya Citizen TV, 1 August 2013, www.youtube.com/watch?v=GGOL4qsZAeE

55 See, for example, 'KIPPRA: Debating the merits of price controls', TTI Stories of Influence, www.thinktankinitiative.org/sites/default/files/KIPPRA\%20Debating\%20the\%20merits\%20of\%20price\%20controls.pdf.
} 
credibly claim to have a 'right to food' movement in the sense that India does for instance (Sinha et al 2014). Government repression and appeasement shows that the structure of political opportunity has not been favourable for movement-building. We find five main factors that account for the weak civic response.

First, the pattern is that disparate groups - mostly registered NGOs operated by professionals - work on different slices of social and economic rights. They only come together occasionally around a moment or an issue, but soon after the collective energy dissipates. For instance, during the campaign for inclusion of social and economic rights into the new constitution, groups working in the human rights and development sub-sectors took part in the 'Basic Needs are Basic Rights' campaign from around 2003 (Nyamu-Musembi and Musyoki 2004). As the inclusion of social and economic rights in the new constitution proved to be rather non-contentious and therefore not visible to the media, the coalition likewise fizzled and faded off and survives in name only. It never seized the opportunity to become a node for popular mobilisation towards a shift in people's thinking, to build a rights subjectivity around issues of material sustenance. A social movement, by definition, must be about working on a sustained basis to shape ideas and influence public discourse, not simply promoting distinct group interests (Chambers 2002; Stammers 1999).

The second factor lies in the broader history of mobilisation for rights in Kenya. It is accurate to say that explicit mobilisation employing the language of rights only came into its own in the struggle against the one-party state (starting in the late 1980s and continuing through the 1990s). It intensified in the clamour for a new constitution, which defined the late 1990s and the entire decade that followed. The struggle against the one-party state focused on political competition and securing the civil and political freedoms that would support it. It construed politics too narrowly and failed to connect the macro-political concerns with grassroots concerns that intertwined political with economic and social repression. ${ }^{56}$ The public face of the rights struggle was that of a professional elite - a few budding opposition politicians, lawyers and prominent outspoken clerics, who were perceived as unable to relate to day-today struggles for basics such as food (Berman et al. 2011; Kanyinga 2004).

These basics were pigeonholed as 'development concerns', the province of an entirely separate cluster of actors - community development organisations. Their focus was one of provisioning: filling the gap left by state non-provision, rather than pressing for accountability for state failure. Their paths did not often cross with those of the 'rights' organisations until the early 2000s (Nyamu-Musembi and Musyoki 2004). A meeting of Kenyan civil society groups in 2003 resolved to adopt programmatic action on economic and social rights (Okello 2004). The effects of this history are still evident. The Unga Revolution did not include in its ranks names such as the Kenyan Human Rights Commission or the International Commission of Jurists, both of them affluent NGOs outspoken on human rights issues since the 1990s.

The third factor relates to financing. Ideally, a movement should be self-sustaining, driven by the willingness of its members to volunteer their time and energy and drawing from existing solidarity. In reality, mobilisation almost never happens without some injection of external resources. So the manner in which the participating entities are financed becomes crucial to the sustainability of the struggle and therefore its prospects for success. The relatively recent turn in international funding practice towards quantifiable time-bound results that are projectfocused (Chambers 2012; Fowler 1991) is incongruent with movement-building. The shaping of public discourse by social movements happens in the long term and the results can be unpredictable, punctuated by gains and reversals which defy the constraints of a project 
cycle. Project-based funding translates into the now familiar pattern of episodic engagement, and the food protests discussed here did not escape that.

As a direct result of the second and third factors discussed above, a rural-urban chasm in mobilisation has emerged as a fourth factor. The kind of mobilisation that gets media attention and seeks direct engagement with high-ranking state officials has been mostly a Nairobi-based affair. With very few exceptions, the rural scene only records small-scale protests such as those we noted in Ikutha. National campaigns around food, as well as those on other dimensions of social and economic rights, ${ }^{57}$ have failed to tap into the energy expressed in these localised protests and to channel it into sustained broad-based mobilisation. To be fair, Bunge la Mwananchi, the chief protagonist in the Unga Revolution, has a structure with a grassroots reach that cuts across urban and rural. However, its leaders acknowledge that they have had more success in organising the urban poor, and their most visible campaigns have been the ones staged in the capital. ${ }^{58}$ This is in contrast to India where the 'right to food' movement draws most of its participation from a rural constituency across the various states (Sinha et al. 2014).

Finally, our review of media reports on food-related protests in the 2007-12 period showed little evidence of strategic use of media to profile the emergent movement and to define the terms of public discourse. Media reports tended to report the confrontation (with police and politicians), mentioning only in passing the issue at the heart of the protest. ${ }^{59}$ There were no fact files on the campaign or any framing of the issues at hand. No media briefing packs were prepared to ensure accuracy and depth in reporting. We found no opinion pieces authored by the campaign's leaders to inform the public, influence opinion and challenge the state's narrative of the food crisis and thereby ensure legitimation of their alternative vision (Hunt 1990). Again, this is in contrast to India where strategic alliances with the media have been central to sustaining the mobilisation, making it relevant to public discourse and impossible for the authorities to ignore.

\section{The Kenyan government's long-term policy}

\section{measures}

We identified six long-term policy measures (some pre-dating the study period and others initiated during the period) whose operation affects food prices directly or indirectly. These measures cover interventions in maize markets, tariff and non-tariff barriers, production subsidies, taxation and social protection and relief. A number of scholars studying food prices in Kenya claim that the package of market policies, including high tariffs, non-tariff barriers and production subsidies, has been consistently directed at safeguarding the production capacities of larger farmers at the expense of millions of smallholder farmers and consumers (Jayne and Tschirley 2010; Fengler and Kiringai 2009; Kiringai et al. 2012; World Bank 2009). More broadly, it is argued that patrimonialism and clientelism have been the underlying cause of inequitable policy and practice in African democracies (Van der Walle 2001: 9). We consider these claims. We then draw on a government review of the

\footnotetext{
$57 \quad$ Examples include a tax justice campaign that has been operated by the National Taxpayers' Association since 2010. Interview, National Taxpayers' Association, Nairobi, 3 June 2013.

$58 \quad$ Interview with Cidi Otieno, (then) President, Bunge la Mwananchi, 3 June 2013.

59 For instance, the 7 July 2011 (Saba Saba) attempt to re-occupy Harambee Avenue to protest the continuing rise of unga prices in spite of the government's promise of action was reported in the Daily Nation simply as 'Nairobi demo turns chaotic, 10 people arrested'. Four short sentences convey the purpose of the protest, the rest of the story describing the clash with police.
} 
performance of social protection policies. We end the section by asking if the long-term policy shows progress towards accountability for hunger in Kenya.

\subsection{Intervention in maize marketing: the National Cereals and Produce Board}

The NCPB has a dual role: it is a price stabilisation mechanism and also operates a strategic grain reserve to deal with crises. As a price stabilisation mechanism it offers a buying price to producers set above the market price when prices are low, and when prices are too high, it then sells its surplus grain to increase supply. Its challenge lies in keeping producer prices high enough to offer incentives to farmers to sell to the NCPB rather than to middlemen, while at the same time keeping prices low enough to ensure access to food for poor consumers (Ariga and Jayne 2010: 221).

Until the late 1980s the Kenyan government set all producer, mill and consumer prices for maize through the NCPB, which had a monopoly on external and internal trade in grains and also stored maize as a contingency against shortage. In the 1980s the NCPB purchased between 600,000 and 800,000 tonnes annually, buying at higher prices and selling at a low price to protect both producers and consumers (Kiringai et al. 2012: 34; Short et al. 2013). In the early 1990s, under economic and other pressures, Kenya liberalised the internal market for staple grains and reduced the role of the NCPB. It continued to play a significant role in domestic grain purchase, however, buying anything from 10 to 20 per cent of Kenyan grain in the 1990s and substantially affecting the market price (Ariga et al. 2010: 4).

Between 1989 and 1994, Jayne et al. calculate that NCPB activities in the market stabilised prices and lowered price levels (2008: 313 ). Its activities during this period kept prices low in times of drought and low production that occurred in 1993 and 1994, protecting consumers from acute shortage. However, the situation changed in 1995. Between 1995 and 2004 NCPB purchases were more often than not at premium prices and appear to have raised wholesale market prices by around 20 per cent, mostly during surplus years (ibid.: 321).

The NCPB's intervention contributes to high food prices in several ways. First, by buying a greater quantity than it sells on the market, the NCPB tightens supply. ${ }^{60}$ Second, the NCPB's declared price sends a signal to producers and informs their decision to sell or store, and also influences negotiations between producers and millers (Gross et al. n.d.: 17). Third, due to a combination of poor transport infrastructure and the NCPB's internal inefficiencies leading to slow decision-making, prices in deficit areas (such as Ikutha) stay high.

Price stabilisation efforts have been shown repeatedly to be capricious, largely driven by short-term considerations that also tend to be political (Gross et al. n.d.: 63). Government responses to price instability have created an unavoidable dynamic between the private and public sector as each anticipates how the other will respond to each other's actions in the market (Jayne 2012). One reason that markets have not integrated more and created more stabilisation is put down to the unpredictable and often untimely nature of the policy and relief response (Jayne 2012; Maitre d'Hotel et al. 2012: 14).

Contrary to expectations that maize producers automatically benefit from rising grain prices, high prices tend to worsen the food security of the majority of farmers (Nzuma 2013: 1). Seventy per cent of smallholders in Kenya are net buyers of maize (Gross et al. n.d: 57). Government statistics place the figure at 63 per cent. These are the people who suffer when prices rise (KIHBS 2006, quoted in Nzuma 2013: 1). Even if they do sell some maize, smallscale producers often have to sell at the time of harvest when prices are lowest either 
because they have no means of storage, are in debt, or in order to meet cash needs such as school fees.

Across all the years since 1995, on average, the effect of NCPB activity has been to transfer income from poor producers and consumers to large producers (Jayne et al. 2008: 323-24; Ariga and Jayne 2010: 236). This finding is consistent with a broader conclusion that Kenya's agricultural policy since colonial times has been skewed in favour of large producers. ${ }^{61}$ NCPB buys most of its maize from large-scale farmers in maize-surplus areas (primarily Western Kenya and the Rift Valley) who make up only 3 per cent of Kenyan farmers, but they account for more than 50 per cent of grain sales. These are the primary beneficiaries of high food prices (Jayne et al. 2008: 323; Ariga and Jayne 2010: 224). The maize-surplus regions also happen to be vote-rich areas, making radical reform of the NCPB politically challenging. Add to that the fact that the large-scale farmers also happen to be either politicians or politically connected:

The people who grow maize for subsistence are not the ones who are subsidised by the cereals board. The maize sector is held hostage by vested interests. The whole thing subsidises 2 per cent of farmers from the North Rift and Kitale who are rich! They sit with us in cabinet and they tell us not to interfere with maize prices. ${ }^{62}$

Counter-arguments include those that suggest that without such a policy, the already significant disincentives for large-scale staple food production would be magnified, the implication being that more disincentives could lead to even greater deficits and higher prices (Short et al. 2013).

With increasing numbers of poor people reliant on food markets, however, some scholars are arguing that governments should concern themselves with lowering food prices through improving infrastructure and freeing trade rather than the now seemingly impossible task of stabilising prices. In a study of price volatility in African food markets, Minot found that those countries with the greatest interventions in maize markets (Kenya, Malawi, Zambia and Zimbabwe) have significantly higher price volatility than those that do not intervene (Minot 2012: 19). Kenya has the highest prices in the Eastern and Southern Africa region (Ariga and Jayne 2010: 234). It seems probable that the uncertainty for private traders produced by unpredictable large government interventions and trade tariffs creates the very volatility the boards are supposed to prevent.

A number of authors concede that world prices, particularly the price of oil, have a significant effect on staple food prices which inevitably have the greatest impact on poor people. Jayne and Tschirley, while agreeing that politics might be part of the problem, propose that there is also an element of ideology (protectionism) mixed with inefficiency in relation to domestic and international price pressures. They argue that ad hoc government entry into and retreat from markets is 'based on the premise that the private sector cannot ensure adequate food supplies in response to production shortfalls' justifying an 'unconstrained role for state interventions in markets to correct for market failures' (2010: 14). They claim that it is not market failure that causes price problems, but underinvestment in public goods (such as infrastructure). They go on to argue for a more market-based, predictable, rules-based mode of intervention into cereals markets. ${ }^{63}$ Other studies support this by suggesting that

61 Colin Leys discusses in detail agricultural policies and institutions in the colonial and immediate post-colonial period, demonstrating that they were designed with large-scale producers in mind. In the post-independence period this pattern was intensified since the large-scale agriculture sector was now an explicit convergence of economic and political power (1975).

62 Interview with member of parliament, Nairobi, July 2013.

63 An example would be the setting of a floor price that reflects a percentage of the import price (say 60 per cent), so that it is slightly below the import price, regionally adjusted for transport costs from the nearest port. Such a floor price would be sufficiently low to deter dumping, while at the same time providing producers with a cushion in the event of a good 
investment in financing maize storage for farmers (to avoid post-harvest over-supply) may do more to improve price stability, as would the removal of regional trade barriers and the improvement of market information and transport infrastructure (Gross et al. n.d: 57).

Intervention through pricing as a policy response calls for further analysis. It is an area full of inconsistencies and internal contradictions. The vehement opposition to price controls for food commodities that led to the hollowing out of the Price Control (Essential Commodities) Act 2011 sits rather uncomfortably with the NCPB's active intervention in maize marketing, as well as with the Energy Regulatory Commission's setting of fuel prices. ${ }^{64}$ These internal contradictions call for a political economy analysis of price controls. When people in Mathare and Ikutha nostalgically recall the days of price controls under Kenyatta, what do they have in mind? It seems that, for them, a moral economy is one in which staple food prices are kept artificially low to protect the poor. The reality of NCPB intervention is on average to raise prices and to create artificial volatility.

\subsection{Ad hoc waiver of import duties on grain}

Kenya's own domestic production of maize has not been adequate for more than a decade. It is continually supplemented by an in-flow of maize from Uganda and Tanzania, formally and informally (Gross et al. n.d.: 17). Since the inception of the East Africa Customs Union in January 2005, Tanzania, Kenya and Uganda lowered their import tariff to 2.75 per cent and also adopted a policy dubbed 'maize without borders.' However, non-tariff barriers continue to be a feature, and the indirect costs associated with them (such as bribes) are passed on to the consumer. A trader going through customs on one of Kenya's borders needs at least seven certificates, usually issued from a major town or the capital city (Randa et al. 2012: 28). A 2007 survey by Gross et al. found that in Kenya and Uganda a typical maize trader could expect six or seven roadblocks per 100 kilometres (n.d.: 57), with the attendant 'informal costs'. They conclude that a regional grain market would help mitigate national supply/demand imbalances and perhaps render unnecessary the ad hoc tinkering with import duties (ibid:: 11).

Outside the customs union, Kenya maintains high import tariffs on maize. Import tariffs for grains were 25 to 30 per cent in 2009 and rose to 50 per cent by 2012 . The government waives import duty temporarily (usually for a six-month period) to allow maize in when it deems it necessary, for instance to cope with drought and other shocks (Gross et al. n.d.: 17). During the period under study, the import tariffs were waived twice - in January 2009 and April 2011.

Analysts point out that the high import tariff regime is a major contributing factor to high domestic prices. Studies in the Eastern and Southern Africa region have shown that prices are less stable, less predictable, and generally higher in countries that restrict grain trade than those with open borders (Gross et al. n.d.: 7). The ad hoc waivers cause uncertainty because they deter traders from acting early to avert shortages, therefore a shortage may get more protracted. In the long term, domestic prices rise above import parity levels (Gross et al. n.d.: 17; Ariga and Jayne 2010: 229). Uncertainty is also introduced by the arbitrariness

harvest that pushes up domestic supply. It would also offer a formula that makes the system predictable for all players. Proposal contained in Ariga and Jayne (2010: 243). Interestingly, a government working party on maize marketing had made a somewhat similar proposal in 1969, recommending that producer prices should be set 'at the relevant export parity price in the different production areas' (Leys 1975: 109), but this was never implemented.

64 A member of the parliamentary committee on energy termed the IMF/World Bank's criticism of the Energy Regulatory Commission's price-setting role hypocritical. He pointed out that while the Bretton Woods institutions are opposed to government fixing of fuel prices through the commission they favour fixing 'the price of money' in the form of setting of interest rates. See A. Shiundu, 'MPs protest high fuel prices', Daily Nation, 16 November 2011, www.nation.co.ke/News/politics/MPs-protest-high-fuel-prices/-/1064/1273670/-/6bdndlz/-/index.html 
of waivers as a policy intervention. It is often ambiguous when exactly the measure takes effect:

Is it following publication in the government gazette? When it is registered in the tax and customs register? When the marketing board announces a new mandate? When [parliament] decides on a measure? When an announcement is made by the Prime Minister's office? When a Minister makes an announcement? Or when a measure is actually implemented at the border?

(Gross et al. n.d.: 54).

Government responses to price instability create an unavoidable dynamic between the private and public sector as each anticipates how the other will respond to each other's actions in the market (Jayne 2012). The unpredictable nature of the policy response is cited as one reason why regional and international markets are not more integrated (Jayne 2012; Maitre d'Hotel et al. 2012: 14). Tariff interventions appear to lack systematic accountability either for stabilising prices or for operating according to clear criteria.

\subsection{Production subsidies}

Kenya has operated a fertiliser and seed subsidy since 2007, based on a new model of subsidies in the Eastern and Southern Africa region that are "pro-poor, targeted and marketfriendly "smart" subsidies' (Druilhe and Barreiro-Hurlé 2012: 19). The subsidy programme is intended to reach 2.5 million 'poor farmers' ${ }^{65}$ of staple crops, providing them with vouchers for two bags of fertiliser in every planting season. Kenya implements its fertiliser subsidy programme by making available fertiliser at a subsidised price through the NCPB depots 'nationwide', but in reality most depots are in maize-surplus areas. ${ }^{66}$ During our research in Ikutha we found no farmers who had benefited from the fertiliser subsidy.

In a survey of subsidy behaviour in relation to agricultural inputs in several African countries, including Kenya, Ricker-Gilbert et al. note that providing low-cost fertiliser, much of which may end up sold on the market by programme managers, can crowd out other supplies, thus not improving the overall amount available (Ricker-Gilbert et al. 2013: 332). Leakage to nonbeneficiaries was identified as a major concern across the Eastern and Southern Africa region. In some countries, as much as 76 per cent of the subsidy opportunity went to the richest one-third of households (Druilhe and Barreiro-Hurlé 2012: 30). In this, and other ways, 'smart subsidies' (targeted inputs) are turning out to be a version of large-scale input subsidy programmes of the sort common in the 1980s (Ricker-Gilbert et al. 2013: 336). As of 2012 , roughly $\$ 2$ billion was spent annually on input subsidy programmes in just seven African countries.

Targeted subsidies are strongly affected by politics, which undermines their efficacy as an equaliser (ibid.: 331). Stated objectives tend to be different from underlying political objectives. The institutional structure for administrating the subsidy programme in Kenya leaves a lot of room for political influence as well as corruption. Guidelines from the Ministry of Agriculture require that the target beneficiaries ('vulnerable farmers') are vetted by a subsidy fertiliser vetting committee at the location (ward) level. ${ }^{67}$ The committee consists of: the chief of the location as chair (a central government employee); ward agricultural

Poor farmers are defined as 'fulltime smallholder farmers who cannot afford to purchase one or two bags of fertilizer at prevailing commercial prices as determined by local leaders in their areas' (Druilhe and Barreiro-Hurlé (2012) p 20.

66 The depot nearest to lkutha, for instance, is located in Kibwezi, 50 kilometres away, in another county. The next nearest depot is in Kitui, the county headquarters, 123 kilometres away, both roads unpaved. At the community forum convened to validate the data for this study, none of the 30 people present had ever sold grain to the NCPB or received subsidised fertiliser, nor did they know anyone who had. Ikutha, 21 March 2014

67 Republic of Kenya, Ministry of Agriculture, Livestock, Fisheries, State Department of Agriculture, Subsidy Fertilizer Distribution Guidelines, 20 February 2014. 
extension officer as the secretary; a local leader drawn from the constituency development committee (which is under the authority of the local MP); a church leader, preferably a lady; and a farmers' representative.

At least having a vetting committee is an improvement on prior practice. Two agricultural officers confirmed that previously there was really no targeting. An agricultural officer in Nairobi could sign off for a farmer to access the subsidy in Kitale, for instance, with no means of verifying the information supplied. However, the list of committee members has all the makings of a forum for rent-seeking, bearing in mind that 'political interference' was reported as one of the main problems plaguing the fertiliser subsidy programme in all Eastern and Southern Africa countries (Druilhe and Barreiro-Hurlé 2012: 31).

Outside maize-surplus areas, the so-called 'low potential areas' such as lkutha register very low levels of fertiliser use (Ariga and Jayne 2010: 242). To have the fertiliser subsidy as the main (largely the only) production subsidy suggests that in spite of the rhetoric in the National Food and Nutrition Security Policy, the policy focus lacks diversity. Our respondents in Ikutha reiterated that the one intervention that would boost production in this area would be investment in irrigation and transport infrastructure.

\subsection{Food security policy}

For most of the period covered by our study there was no up-to-date policy governing food security in Kenya. In 2007 the Kenyan government proposed the National Food and Nutrition Programme, a draft policy paper to update the existing policy dating from the 1980s. The 2007 draft policy departed from prior emphasis on maize self-sufficiency to more comprehensive food access, diversity and nutritional status (Republic of Kenya 2007). It recognised that high staple prices only favoured producers of surplus, while hurting urban consumers and the great proportion of rural producers who were net buyers. It proposed gradual lifting of import duties on grains, as well as removal of restrictions on cross-border trade (Ariga and Jayne 2010: 227). The draft was not implemented, and instead a new set of policies was drawn up and adopted by the cabinet in 2011: the National Food and Nutrition Security Policy (Ministry of Agriculture) and the National Social Protection Policy (Ministry of Gender, Children and Social Development).

The Food and Nutrition Security Policy (2011) begins with the constitutional right to sufficient and nutritious food. It stipulates that funding to the food and agriculture sectors will be increased to 10 per cent of the national budget (Republic of Kenya 2011a: 13). The question is whether it contains the right prescriptions to fulfil the constitutional commitment. It begins with the assumption that food accessibility is primarily endangered by 'climate change, global energy prices and globalization,' indicating that external forces are to blame and self-

sufficiency continues to be the primary response (ibid.: 4). With regard to food availability, the policy proposes better production, storage, markets, strategic reserves and rural and urban employment. Encouragingly, it promises 'more predictable and transparent state involvement in markets, particularly in changes in import tariffs and in NCPB purchase and sale' as well as 'adherence with EAC and COMESA ${ }^{68}$ trade policies' (ibid.: 16). Its glancing reference to a macroeconomic framework that will address high food prices seems inadequate, however (ibid: : 11).

The policy mandates continued agricultural input subsidies, increasing the strategic grain reserve, promoting private sector use of public storage facilities and building the infrastructure to encourage local supplies into local markets and between surplus and deficit areas. It is silent on the much-debated problems of unequal access to subsidies and 
facilities, and on the inefficiencies in the strategic grain reserve and NCPB purchase and sales.

On the achievement of adequate nutrition, the policy is on surer, if very much more limited ground. It notes children's constitutional right to proper nutrition and health care and lays out a number of areas of government responsibility for nutrition promotion and provision of supplements for new mothers, infants, adolescents, adults and older people. On relief and welfare, the policy offers continued food relief in rapid-onset emergencies, cash transfers, including cash for work (building assets like roads and dams) and cash safety nets for people who are chronically poor. This area is then covered in more detail in the National Social Protection Policy (Republic of Kenya 2011b). Neither document tackles the limitations of the current relief and welfare programmes in terms of cost, inadequate coverage and corruption. The National Social Protection Sector Review (Republic of Kenya 2012) goes into more detail on achievements, potentials and problems in delivering social protection. In the next section we will draw on that review to evaluate briefly the main government and donor programmes for social protection and relief.

\subsection{Social protection and relief}

The differential effects of the food price spikes throws into relief a deepening class divide in Kenyan society; a divide across which market policy has so far been unable to throw an adequate lifeline. Poor people are the first to suffer and yet receive the least support. Is social protection an alternative? Can it fill a gap while economic growth creates employment? It is one means by which the state has tried to deliver on its promise to keep Kenya's poor people from hunger.

The importance of social protection was underlined by the UN Special Rapporteur on the Right to Food: 'As long as gaps remain in social protection, however, food price inflation will continue to be a serious threat to the right to food of low-income households. ${ }^{69} \mathrm{~A}$ recent review of social protection in Kenya reports that from 2005 to 2010 social protection expenditure rose from KSh33.4 billion ( $\$ 371$ million) to KSh57.1 billion, or 2.28 per cent of GDP (Republic of Kenya 2012: vi). The bulk of this involved spending on contributory programmes for public and private sector employees including the civil service pension. External donors picked up most of the tab for the relief and the hunger safety net programmes, covering 71 per cent of the costs (ibid: vii-viii).

Does the existing social protection system amount to systematic provision? The first question relates to affordability. The review notes that Kenya could afford a comprehensive social protection programme within nine years (costing KSh5 billion), only if it exclusively targeted households with orphans, vulnerable children and the over-60s, and people living with HIV/AIDS. Even for this, the programme would need to be more efficient, and economic growth would need to continue at 6 per cent per annum. The calculation does not take into account relief spending (ibid: : xii).

The second question relates to coverage. In recent years, relief and transfer programmes have covered up to 14 per cent of the population, i.e. around a quarter of those who are below the poverty line. Inclusion means different things in different places, however. With the donor-funded 'Hunger Safety Nets Programme' (HSNP), it means regular monthly income support (around KSh2,000 per household (\$22) in 2012), enough to buy around half a kilo of maize meal a day. In other programmes it might mean an unpredictable 10 kilos of unmilled 
maize once a year. Existing programmes are generally small (19 programmes with a median size of 120,000 beneficiaries in 2012) and housed in a range of different institutions (ibid.: x).

The HSNP covers a small proportion of very poor people very efficiently. Until recently, it covered four pilot districts in the arid and semi-arid areas, reaching 289,000 people in 2010 (ibid.). Smaller urban cash transfer programmes include the National Urban Social Protection Programme, piloting cash transfer to targeted households in Nairobi's Mukuru and Korogocho informal settlements. The programme provides each of the 5,000 households with KSh1,500 per month via the MPESA mobile telephony-based electronic transfer money system. These two programmes collect detailed data, make complex targeting calculations, monitor closely and make continuous adjustments. Their comparative cost is very high. ${ }^{70}$

\subsubsection{Relief projects and programmes}

Between 2006 and 2010 the World Food Programme (WFP) distributed annually between 223,000 and 245,000 tonnes of food in Kenya. The total number of beneficiaries varied between about 4 million in 2008 to more than 6.6 million in 2009. WFP reported assisting between 10 and 17 per cent of Kenya's population between 2005 and 2010 (Word Food Programme 2011: vii). ${ }^{71}$ The greater proportion of the programme is general food distribution, with small amounts allocated to school feeding, food for work and supplementary nutrition. Food (or cash) for assets (public works) ${ }^{72}$ reached 726,400 people in 2010 (ibid.: ix). A daily school meal was allocated for 1.2 million children, half of which are supplied by the government and the other half by WFP and its partners (ibid.: ix). WFP spent $\$ 1.6$ billion on these programmes between 2006 and 2010, to assist between 10 and 17 per cent of the population. The question arises as to how the government of Kenya and its international supporters could possibly increase coverage to all the hungry people in the country. These food supplies are enormously important to poor people and to Kenya's ability to avoid famine.

The relief programme was widely criticised during our focus groups and interviews. People in Ikutha saw it as having deteriorated rather than improved. It would appear that an exclusionary discourse of vulnerability has crept in over the last decade or so (since Moi's departure), narrowing the basis for eligibility, shrinking the net of relief, eroding expectations of the state, and creating room for manipulation and corrupt practices by local administrators. People spoke in terms of a distinct break between 'back then' and 'now':

In years gone by, whenever relief food arrived it used to be off-loaded on the same day and people would have been told in advance that relief food was expected, so they would be there waiting. But now when food is stored in the DC's [district commissioner] camp, a lot goes on there that is not open. ${ }^{73}$

When I was little I remember such a process [of involving area residents in identifying beneficiaries of relief food]; but now I don't see it. These days they only meet behind closed doors in their offices. In those days we would all be called to go and register with the Assistant Chief. We would pay some money, but once you paid you got registered and you definitely got the food. ${ }^{74}$

\footnotetext{
Interview, HSNP Secretariat, July 2013

This figure includes 300,000 refugees. Most of the funding comes from the United States, but the figure also includes releases from the Strategic Grain Reserve valued at \$32 million (WFP 2011).

72 The food (or cash) for assets programme has been implemented as the Protracted Relief and Recovery Operation (PRRO) since 2009. In lkutha the local term coined for it is Katulu, which is the name for the red squirrel, so called because all the works projects involve digging (earth dams, terraces etc.).

Focus group discussion with small-scale market women, Ikutha.

Focus group discussion with traders in outlying markets, Ikutha
} 
In Kenyatta and Moi's time mwolyo (food aid) used to be given in a good way: $10 \mathrm{~kg}$ per person, even [for] a small child. Now government food aid and even Katulu goes to the wrong people. I know of families where children have been orphaned; they have no adult living in that home; it is just children on their own... And then such people do not end up on the food aid list. Who then is on that list? ${ }^{75}$

But in the past the government was very good with food aid at times like those. I recall during 'yua ya ndeke' [the famine of the aeroplane, estimated as 1961/62]. The bridge had been destroyed by heavy flooding so the government was air-dropping relief food. The aeroplanes would drop huge quantities of food. The sacks burst open as they landed. Anyone who was able-bodied ran out to collect grain. You ran out, and you gathered as much grain into a heap as you could, then you sat on it. If I am stronger than you and I find you sitting on your heap I would push you off and take your grain, then you have to run off and gather somewhere else. I will bundle up that grain into my leso [wrapper worn around the waist by women], and carry it home, pour it on my floor and run back to collect some more, till my family had enough. But because there was so much grain, in the end everyone had something to take home, and there would still be grain scattered around hours later. The slow ones would still be picking up their grain at that time...

Because there was plenty anyone who was able to come out managed to collect. Nowadays there just is not enough, so you are told "You are getting help from Katulu," you can't get the government relief food". 77

In addition to programmed food relief in poor areas, there are also emergency responses, such as the short-term provision of subsidised maize meal in December 2008 for some 40,000 urban poor, discussed above.

In response to the growing unemployment crisis of 2009, the government introduced the Kazi Kwa Vijana (Work for Youth) scheme, making available KSh6.6 billion ( $\$ 80$ million) for wages for public works. Kazi Kwa Vijana was roundly criticised by young people, who said the jobs it offered were short, difficult to get and, though better than nothing, very low- paid and hard labour. In 2011 the World Bank withdrew its funds from the programme after an audit showed losses of millions of shillings (Mutiga 2011).

Finally, the Ministry of Agriculture operates its own cash transfer programme known as Njaa marufuku [hunger eradication]. Community groups and registered NGOs access the funds by submitting a proposal for projects that promote food security, either in crop farming or in livestock production. Grants to community groups amount to KSh150,000 while NGOs can access up to KSh2 million. ${ }^{78}$ Since the programme was not mentioned at all during our research in Ikutha, we raised the question at the community feedback forum. A district agricultural officer present confirmed that the programme does exist. She then explained that having received no other applications, all the grants so far had gone to groups undertaking horticultural farming along the banks of the Athi - an area of Kitui South district that could be described as 'food secure'. Ikutha residents' experience of the programme was summed up by one woman's comment: 'The njaa we have seen, but the marufuku not.'79

\footnotetext{
Focus group discussion with Farmers' group, Ikutha

The World Food Programme's Protracted Relief and Recovery Operation (PRRO).

Focus group discussion with Katulu women, Ikutha

Interview, Food Security and Early Warning Programme, Ministry of Agriculture, 22 July 2013.

Community Feedback Forum, Ikutha (to discuss this study's findings), 21 March 2014.
} 
The complaints from the countryside notwithstanding, there are great plans inside government: a disaster management authority, contingency plans, food price subsidy, food aid, cash transfers, expanded social protection, insurance for farmers, contingency funds, proper registration and biometric cards are all on the table. ${ }^{80}$ One policymaker, however, spoke of gross underfunding for social protection activities. ${ }^{81}$

With respect to social protection measures, the Social Protection Sector Review notes that few of the programmes, especially on the safety net side, are anchored in any statutory framework (Republic of Kenya 2012: 71). Donor-funded programmes tend to have stronger governance and are subject to a higher level of scrutiny than those funded by the government. In terms of accountability to beneficiaries, there is sometimes involvement of local communities in selecting beneficiaries, but little else. Only the HSNP has a comprehensive system to manage complaints involving volunteer committees and systematic responsiveness, but even this programme is not connected to formal sanctions for failures. Government services often have service charters and complaints boxes at reception offices (ibid:: 74). There are no sector-wide minimum standards, no comprehensive performance management systems and, as yet, no consistent effort to disseminate data on social protection programmes using the Open Data Initiative (ibid:: 76-84).

In its analysis of the politics of programme effectiveness, the government's review reports that political leaders are concerned that social protection, particularly safety nets create dependency among poor people. On the other hand some of the programmes owe their existence to being championed by political leaders. One MP is currently championing the rights of people with disabilities to social protection support. In another case, MPs have debated universal pensions for older people (ibid.: 100-2). With this kind of political support, and with a sustained push by external donors, the social protection system appears to have made advances in recent years. Nonetheless social protection is not yet accountable and adequate to deliver on the right to food. Food deliveries and cash payments are erratic, hard to access and lack transparency (ibid.: 87). With the wide variety of ministries and other government agencies involved, each with their different mandates and systems, 'institutional sustainability is determined to some extent by how they are financed and who champions the programme' (ibid: : 98-99).

\subsection{Exemption of essential food items from VAT}

The VAT Act of 2013 states that certain specified food items, including unga, are exempt from VAT ${ }^{82}$ Also listed as exempt are agricultural inputs such as fertiliser, maize seed and agricultural pest control products; and various types of medical supplies. ${ }^{83}$

It is estimated that VAT accounts for 46 per cent of Kenya's tax revenue. ${ }^{84}$ VAT replaced sales tax in 1990 and has been a significant source of revenue (Karingi and Wanjala 2005: 8). Kenya relies predominantly on indirect taxes because:

Indirect taxes are easy to collect, you don't have to look for the individual taxpayer, you identify businesses who remit it. It is almost zero cost in terms of tax administration.

\footnotetext{
80 Republic of Kenya, 2013, Budget Statement for the Fiscal Year 2013/2014.

$81 \quad$ Interview, Social Protection Secretariat, Nairobi, 9 July 2013.

82 The long list includes soya beans, uncooked groundnuts, various seeds from which cooking oil is made (cotton, sunflower, sesame etc.), unprocessed milk and milk specially prepared for infants, maize (corn) flour, semi-milled or wholly milled rice, ordinary bread, gluten bread and unleavened bread, and 'fresh birds eggs in shell'.

See First Schedule to the VAT Act No. 35 of 2013.

Interview, National Taxpayers Association, Nairobi, 3 June 2013
} 
The only tax administrative cost is on compliance - regular checks with the big stores. After the introduction of the Electronic Tax Register (ETR) it is even easier to monitor. ${ }^{85}$

Food items such as maize meal, unprocessed grains, beans and milk have enjoyed a zero rating since $2003 / 4 .{ }^{86}$ It is the zero rating of these and other non-food goods that the VAT bill of 2012 sought to eliminate, sparking protest both from civil society and a section of parliament. The 2012 bill had only retained exemption for unprocessed foods, tax officials arguing that this would cushion the poor as they consumed mostly unprocessed goods. ${ }^{87}$ However, critics were quick to point out that this was not the case for the urban poor.

There are divergent views on whether and how the tax regime, specifically VAT, can be employed for welfare ends. The view that supports a regime of exemptions and zero ratings concedes that these are blanket measures on the goods, which do not target the poor. On account of this failure to target, critics of exemptions argue that the tax regime should be applied uniformly, while interventions to benefit the poor should be reserved for the expenditure side, in the form of targeted subsidy programmes and other social protection measures. This was the position of the Kenyan Revenue Authority, and was also expressed by the Kenyan Association of Manufacturers. ${ }^{88}$ However, the spectacular failure of such a subsidy programme in the short-term measures of 2008/9 points to the need to invest in administrative machinery that would overcome the challenges of corruption.

A third view favours looking beyond VAT to broader reform of the tax administration system: extending taxation to the lucrative parts of the informal economy, increasing collection rates for already approved taxes, such as the tax imposed on landlords (allegedly the Revenue Authority had only collected ten per cent of this), and sealing tax loopholes such as transfer pricing and tax exemptions that do not translate into any benefit for the country. ${ }^{89}$

Is the exemption of food items likely to stay? As discussed above, both when introduced in $2003 / 4$ and then retained in the VAT Act of 2013, there were peculiar political circumstances that propelled the exemptions for essential food items. Given that VAT has been the 'choice instrument for dealing with exceptional circumstances and unexpected expenditure' (Karingi and Wanjala 2005: 9), the strength of the moral economy will determine whether the government will opt to simply pick the low-hanging fruit (i.e. put VAT back on exempt and zero-rated goods) or whether it will invest in more demanding long-term measures such as expansion of the tax base.

Has the VAT exemption on food and agricultural goods had any effect on price? Has it benefited (or will it benefit) the poor? It certainly helps not to have an additional 16 per cent on already high prices, but it does not cushion the consumer from other effects such as the price of fuel, and therefore higher transport costs which traders pass on in full. In addition, tax experts are unsure whether tax measures produce targeted relief (ibid.: 18), and

Interview, National Taxpayers Association, Nairobi, 3 June 2013.

See Value Added Tax Act, Cap 476 (repealed), Fifth Schedule, Part B: 'Zero-rated goods'.

Kenya Revenue Authority, 'The Case for VAT Zero Rating to Achieve Social Policy and Distributive Objectives' (undated, on file with authors). The title of the paper is misleading as it devotes more space to arguments against zero rating.

Kenya Revenue Authority, 'The Case for VAT Zero Rating to Achieve Social Policy and Distributive Objectives' (undated, on file with authors): 'Under a liberalized economy, taxation is a weak instrument of targeting the poor - only expenditure can target the poor effectively' (p.3). See also K. Njoroge, 'As food prices rise, brace yourself for an Unga war', Daily Nation, 18 June 2013; email interview, Policy Compliance, Risk Management and Research Division, Kenya Revenue Authority, Response date: 9 September 2013; email interview with former KRA official, Response date: 5 September 2013

See K. Njoroge, 'As food prices rise, brace yourself for an unga war', Daily Nation,18 June 2013; Interview, Nationa Taxpayers Association, Nairobi, 3 June 2013. 
therefore whether the government can point to the VAT exemption as a measure that brings food affordability for the poor.

\subsection{In summary: Is this accountability for hunger?}

While it seems that there is no agreement on how price hikes can be prevented or food insecurity mitigated at the required scale, it is clear that current policies are not delivering. Food prices in Kenya went up more sharply and stayed high for longer than most other countries in the Eastern and Southern Africa region. Social protection covered only a small proportion of the needy and food relief has come in for much criticism by its recipients. The government's own internal review of the social protection policy concedes that current measures do not amount to accountability.

The mandate to protect Kenyans from hunger exists at a constitutional level, but has not been translated into legislation that can underpin agricultural, market, taxation or social protection policies. There are as yet no standards set for the meaning of a right to adequate food of acceptable quality. Monitoring systems exist for prices, incomes and nutrition levels. However, in the absence of standards and specific legislation, these systems churn out information that is of limited use in identifying failure and attributing responsibility for it. Sanctions for failure are absent.

The battle for self-sufficiency is not being won, the structural maize deficit is growing, prices are rising, relief is plugging only some of the gaps and, as a result, undernourishment is threatening to become the norm for millions of Kenyans. As Kenya's poor consumers multiply in number and voice, the moral economy is increasingly an issue of citizen debate.

\section{What accounts for the persistent failure of accountability for hunger in Kenya?}

One thing is clear: there is not a lack of state capacity to create a system of accountability for hunger. As already noted, Kenya has an acclaimed system for famine early warning and response, albeit one alleged to be partly driven by short-term private gain. Nonetheless it has worked to keep famine-related casualties low, and fatalities almost eliminated (World Food Programme 2011). Based on our discussion so far, we can identify five inter-related factors that account for the persistent failure of accountability for hunger in Kenya.

\subsection{Political economy of food and agriculture policy in Kenya}

The people who grow maize for subsistence are not the ones who are subsidised by the cereals board. The maize sector is held hostage by vested interests. The whole thing subsidises 2 per cent of farmers from the North Rift and Kitale who are rich! They sit with us in cabinet and they tell us not to interfere with maize prices. ${ }^{90}$

Kenya is defined by a dovetailing of economic and political power, sharply manifested in the food and agriculture sector. A post-colonial elite inherited the colonial practice of subsidising large-scale farmers, and very quickly, inherited privilege congealed into entitlement secured by political clout. The favouring of maize-surplus areas both in pricing policy and production subsidies bears witness to this. The maize-surplus areas of Rift Valley and Western Kenya also happen to be vote-rich areas, so that any suggestion of radical reform of the NCPB raises political temperatures. By contrast, far-flung Ikutha can be safely ignored, and three years of cyclical drought and chronic food shortage can fail to register on the political radar 
screen. Rumblings in urban slums can be 'waited out', repressed, or appeased with hurriedly crafted programmes that are not intended to last.

\subsection{Weak moral economy}

There is little evidence of consensus on what legitimate expectations people can have of the state in times of food crisis. Reading and listening to the views expressed by the Unga protesters, one might come away with the impression that a strong sense of citizen entitlement and government obligation with respect to food does exist. The protests carry a strong belief in a government's responsibility to ensure that the price of basic commodities such as food and fuel does not rise beyond the reach of 'the ordinary person'. It is implied in the choice of forum and audience; in the persistent disruption of 'state' events; and in the symbolic highly publicised physical delivery of (or attempt to deliver) a petition to a specific government official. The gesture carries with it a message of attribution. The speeches and slogans make explicit a belief in citizen entitlement (especially for the poor) and government obligation:

The price of maize meal and other essential commodities should be reduced to cushion the poor against the high cost of living. ${ }^{91}$

The government should urgently reduce the price of essential food stuff and ensure matatu fares are also reduced. ${ }^{92}$

\section{They cannot eat when we are not eating. ${ }^{93}$}

We wish to remind Mr Rotich [Cabinet Secretary for Finance] that he has misled the president. We are disappointed that even after coming from a humble background, he has failed the moral test by turning his back on the poor. ${ }^{94}$

However, these protesters' sentiments can only be said to represent a sense of the moral economy around food if they are legitimated beyond the protesting groups. E.P. Thompson said of the eighteenth century food protests in England:

By the notion of legitimation I mean that the men and women in the crowd were informed by the belief that they were defending traditional rights or customs; and, in general, that they were supported by the wider consensus of the community. On occasion this popular consensus was endorsed by some measure of licence afforded by the authorities. (Thompson 1971: 78).

Some of the views expressed in the focus group discussions undoubtedly suggest a degree of wider community consensus on the existence of citizen entitlement and government obligation, in particular in times of food crisis:

Comment attributed to Professor Yash P. Ghai, former chair of the Constitution of Kenya Review Commission that presided over the process of enacting a new constitution, which culminated in the 2010 constitution. Professor Ghai was taking part in the fuel price protest led by COFEK on 19 April 2011. See 'Kalonzo urges patience over cost of living', Daily Nation, 19 April 2011, www.nation.co.ke/News/-/1056/1147378/-/10ycd5iz/-/index.html

Attributed to Paul Muite, former MP and a lawyer, who since the 1990s is always on hand to secure the release of demonstrators and other dissenters taken into police custody. See 'Kalonzo urges patience over cost of living', Daily Nation, 19 April 2011, www.nation.co.ke/News/-/1056/1147378/-/10ycd5iz/-/index.html Comments of an unidentified protester during the 31 May 2011 protest. The Minister for Finance had just announced the
government would stop using Mercedes-Benz cars and would instead assign Toyota cars in order to save on fuel costs, a downgrade that some ministers opposed. See video clips from Citizen TV and NTV respectively: www.youtube.com/watch?v=GaTG8CgFKyU and

94 Attributed to 12-point petition presented by COFEK-led protesters. See A. Mutambo, 'Groups stage demo against 'unga' taxes', Daily Nation, 2 July 2013. 
As the members of parliament are fighting for [an increase in] their salaries, where do you think that money is coming from? It will come from the increased cost of flour. When they tax those kinds of goods, it is going to them. They are the ones who are supposed to help us, but with how they are behaving, who will we cry to ${ }^{95}$

However, there was also a strong sentiment that at a specific historical moment such a moral bargain had ruptured. That specific moment was identified as the imposition of soko huru (free market) under the Moi regime in the early 1990s, when price control was abolished (under the Structural Adjustment Programmes):

Things were good during Kenyatta's time because if he instructed that the price of a certain thing should go up by one cent, that is what happened. If his officers found that you had increased it by more than that, you would be punished. ${ }^{96}$

In a way, price controls, like we had before Moi's time, would help ... The government would select basic commodities and set the price for those at a level where even the person at the bottom can afford. ${ }^{97}$

If they say that flour is KSh80, they should send policemen to check if there are people who are selling it at a higher price. The government should take care of us. ${ }^{98}$

Does the government, by E.P. Thompson's criterion, at least endorse the view of the moral economy articulated in the protests and by some in the research sites?

There are instances in which government officials feel compelled to concede (or at least not dispute the claim) that the government has an obligation to cushion the poor against the high cost of living. Examples include MPs' support of the campaign to exempt food items from VAT. The parliament's minority leader was quoted in the press as having said that the poor must be cushioned from the extra burden that would be imposed by VAT on food items, adding: 'If any measures are brought here through VAT that hurts the poor man we shall reject them ... We don't want those who live in poverty to be taxed harshly. ${ }^{\prime 9}$

Another example, discussed above, is that of the MPs who led the crusade for price control legislation against the tide of free-market sentiments of the business and policy research community with a like-minded president on their side. The two successive presidential pledges and the acceptance of the unga petition by the prime minister also suggest concessions to a moral economy.

Beyond the politicians, officials from the Kenyan Revenue Authority and the Treasury were careful during the VAT debate not to directly question the existence of an obligation to the poor. Rather, they sought to dislodge critics from the moral high ground by dwelling on the argument that the existing regime of exemptions and zero ratings was not based on any research establishing that it did indeed benefit the poor. ${ }^{100}$ They argued that the existing regime had become captive to unscrupulous merchants adept at manipulating the inefficient refunds system. Cabinet Secretary Henry Rotich justified the VAT bill to parliament's Budget and Appropriations Committee in terms of closing 'revenue leaks in the current VAT Act.'101

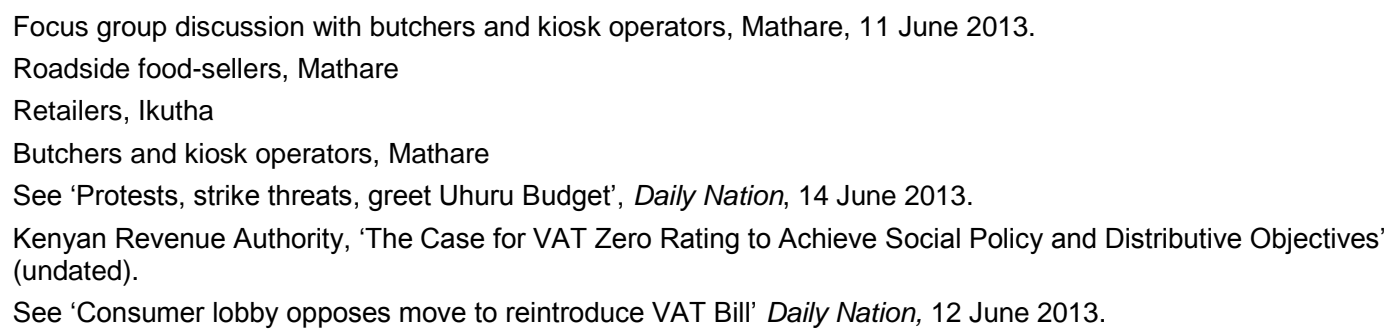


This way, government officials do not come across as disagreeing with the idea that the poor ought to be protected. Rather, they sought to frame the debate as being about what kind of protection worked best. In their view, interventions on the expenditure side would work better and have fewer distorting effects than exemptions (i.e. apply a uniform rate of tax, then invest in subsidy programmes targeted at the poor). ${ }^{102}$

If the government at the very least concedes the protesters' claims to a moral economy around food, what then should we make of the violent repression of protest? A pessimistic interpretation is that the conviction does not run deep enough; that some politicians and officials are only willing to give a nod in the direction of the moral economy asserted by the protesters, or are forced by political expedience to do so. A more optimistic reading is that 'government' is varied; that there are some within government who do have a conviction about a moral economy around food, which can be boosted by the pressure of sustained popular mobilisation to translate into an overall change in policy direction.

\subsection{The right to food has not taken root}

The 2010 constitution provided for the first time the right to food, as well as the rights of consumers to goods and services of reasonable quality. Protesters made explicit reference to these rights statements to establish an ethical basis for the government's obligation to take action to protect its citizens from the effects of the food price hikes. In the court case that COFEK filed concerning the high fuel prices, COFEK framed its claim in terms of a breach of economic and social rights under Article 43 of the constitution, specifically, violation of the right to be free from hunger, as staple commodities such as unga had become unaffordable. COFEK argues that the government agencies concerned have regulated the energy sector in a skewed manner that benefits petroleum companies at the expense of consumers.

Before protesters embarked on their attempt to re-occupy Harambee Avenue on Saba Saba Day in 2011, they assembled at the busy Kencom bus terminus and read out these and other articles of the constitution to the crowd of onlookers. At the terminus, speakers emphasised to this urban audience that the government has historically treated freedom from hunger as a rural issue centred on droughts. It is time, the Bunge convenor announced, that the government took seriously the right of the urban poor to be free from hunger. In the anti-VAT protests of June 2013 Bunge la Mwananchi termed the Treasury's proposal to levy full VAT on essential food commodities as a violation of Article 43 of the 2010 constitution (Mutambo 2013).

In the focus group discussions we sought to understand how the idea of a right to food was viewed, and whether people might conceive of it in ways that are likely to spur mobilisation towards accountability for hunger. The views expressed are a mix of restrictive and expansive interpretations of a right to food. The restrictive view saw the right to food simply as direct provision of food by the government. A right to food equals 'free food'. This view limits the right to food to simply food aid; to situations of extreme destitution. Indicative excerpts are reproduced in Table 4.1. 
Table 4.1 Restrictive view of the right to food

I find it hard to say that the government should provide food. I think they should give money to groups to start businesses.

Perhaps those who are really poor should be called to go and pick that food, but those who can depend on themselves should be given work to do.

Butchers and kiosk operators, Mathare

When you are strong you must work with your own hands. ...But an old person can be given food for free.

Internally displaced persons, Mathare

If there is a right, then there should be more slots on the Katulu [the food-for-work/ cash for assets programme].

Self-help groups, Ikutha

But we have not had good rain for the last three years; not the nthwa rain and not the uuwa rain. Yet we are told the aid is only for the very old and the widows; but everyone is suffering. So there is not really a right.

Katulu women, Ikutha

I see it as a right to access food, but you still cannot access without money, so l'm not sure whether to call it a right or not.

Food is one of the basic needs, but you are the one responsible to get that food. So, in other words, I have a right to struggle for food.

Youth, Mathare

You cannot say you have the right to eat and you aren't even bothering to look for food. It is my responsibility.

Vegetable sellers, Mathare

In this restrictive view, the category of rights-holders is narrowed down to those seen as 'vulnerable' or unable to feed themselves due to circumstances beyond their control. Viewed in this manner the right to food has little potential to catalyse broad-based mobilisation.

The expansive view recognised that a right to food had to mean more than simply receiving 'free food' from the government. Here the emphasis was on the long term; on enabling access to food and facilitating the ability to feed oneself. Thus, government measures such as regulation of food traders, stabilisation of prices, and investment in supporting production (for instance, through irrigation projects) was seen as being at the core of what a government must do in order to fulfil its obligation under a right to food. The excerpts below sample this expansive view. 
Table 4.2 Expansive view of the right to food

It means that the price of food should be lowered by the government so that people eat well.

Dhobi women, Mathare

I think it means that a person should be given a way to acquire food.

We can't depend on government relief food. Even if relief food were given every day for a whole year what happens to us after the one year? What we need is the means to feed ourselves. We just wish they would decrease the cost of food.

Internally displaced persons, Mathare

The government should make sure that the cost of food remains consistent/stable; we are ready to work hard for our food.

Vegetable sellers, Mathare

I see it as a right; it means that the government must control the struggle; make sure it does not become too hard. This is because the government can control the cost and availability of food. They can do this by reducing taxes so that we can afford food.

Youth, Mathare

Since the study did not employ survey methodology, it is impossible to quantify the relative weight of each view, but we got the impression that the restrictive view was more prevalent. Taken together with views that expressed outright cynicism about the utility of a right to food (see Table 4.3) these perceptions of the right to food explain why it has not become a galvanising force since its adoption in 2010.

\section{Table 4.3 Cynical view of the right to food}

The constitution sometimes lies to us because they haven't told us where we will find that food that is our right ... You will die of hunger if you overstate the importance of that constitution.

Roadside food-sellers, Mathare

I have a right to complain and defend that right [nina haki ya kuitetea]. But I don't have the ability because I don't know where to complain - I don't know where to start. I know that the government has the responsibility, but how do I get that right from them?

Vegetable sellers, Mathare

We play our part by paying the price of the food. I think it was put in the constitution as a right simply to blind us. If you go to claim it - unanyoroshwa! [you are dealt with] That right to eat is just words. Because no one in government will follow up with that story.

Youth, Mathare 
As concerns that right to food, well, I didn't know that it was a right. All I know is that if I come by food I will eat, and if I don't come by any then I won't eat.

Now, even if that constitution says food is a right, there has to be some person between me and that constitution, in order for it to mean anything. I can't take the constitution with me and go to the $D C$ [district commissioner] and say "this paper here says I have a right to eat." In fact I expect no help at all from those offices.

Retailers, Ikutha

On that issue of food, the 'haki' (right) does not quite fit, because the food is too expensive for most people.

Charcoal burners, Ikutha

It means you are absolutely free to eat food if and when you can find it [Ni kuya wawona!]

There is a big gap between the paper and the reality. The right is for everyone; but how will each person actually get the food? Not everyone will get to eat or eat enough.

Traders in outlying markets, Ikutha

There has been a lukewarm reception for not only the right to food, but for economic and social rights in general within government. Note the absence of a legislative timetable for laws to implement the Bill of Rights, yet all 'new' issues in the 2010 constitution were assigned a timeframe within which parliament is under obligation to enact implementing legislation. With the exception of social protection quarters, the message one gets from government - especially the Treasury - is that rights do not dictate the direction of policy. ${ }^{103}$

How deeply rooted is the constitution in the day-to-day interaction between citizens and officials or politicians? Informal rules and ethnically defined identities and modes of engagement eclipse the formal system archived in constitutions. ${ }^{104}$ The mindset of politicians is still largely based on patronage (Berman et al. 2011). The short-lived provision of subsidised maize meal in 2009 is a case in point. It was not a carefully considered government decision anchored in any legal or policy framework, nor backed up by commissioning of the relevant institutions with a mandate over food security or social protection. Also absent were channels for handling citizen complaints or simply an inquiries or information provision system. Asked how such a poorly thought-out intervention could have been rushed into implementation, three senior government officials we interviewed answered simply 'politics'; the need for politicians to be seen to be doing something for the starving masses. Another incident illustrating how patronage is the politicians' frame of reference is the attempt by Mike 'Sonko' Mbuvi to take over the Unga Revolution, to be seen as its patron. 


\subsection{Failure of electoral representation}

We thought those we voted for would help us. ${ }^{105}$

The notion that the rich and powerful have obligations towards the poor majority has deep historical roots predating colonialism (Berman et al. 2011). However, the articulation of these obligations in the colonial and post-colonial period has taken on an increasingly materialistic and sectarian theme, in the extreme providing a justification for corrupt and unaccountable leadership: as long as 'our own' is in power.

At bus stops, market stalls and street kiosks, there is a constant refrain to the chorus of disappointment and resignation at the behaviour of political leaders. 'I went...', 'I asked...', 'I picked the one I thought would...', 'I hoped...', 'I expected...', '... but, nothing, nothing.' The politics of patronage - invariably tied to ethnicity - still play a significant role in shaping the expectations that people have of their political leaders: 'When we had a prime minister [i.e. when he was of our tribe], we had access ${ }^{\prime 106}$.

Experience has told people that their political leaders, who have helped divide up the polity into tribalised factions, will make a show of rewarding their people for their votes. But at the same time many of those we spoke to admit that once elected, leaders of their own tribes do not necessarily make any efforts to respond to their own people. They disappear to parliament or the county capital and are not seen until the next election. Tribalism is not about primordial identity, but about distribution of goods. It works at the level of national politics, and also, remorselessly, at an individual level. 'I remember our group was Kikuyu and we would pay the price of KSh150 [for the subsidised unga], but my non-Kikuyu friends were asked to pay a higher price,' recalled one activist in Mathare.

Hand-outs of money in election years dampens protests about food and employment. Campaigning politicians distribute substantial amounts of cash to potential voters, from their own and allied tribes. Aware that accepting the money is not quite in line with democratic rhetoric, people tend to say that it is others who accept the cash. There is some debate about how people actually vote after the money is given, but it would seem that for many the money is not so much a purchased vote, as a reward for belonging to a tribe and accepting its political leader. As such there is something of a patron-client relationship attached, which is not so much about the purchase of multiple individual votes, as about the tendency for politics to work in tribal blocs over long periods.

People were being given KSh1,000 [\$12] the night before in order to influence how they would vote. There are many people who won't have seen KSh1,000 all at once in their entire lives, so this is a big deal. But still I think we all voted knowing very well what our problems are, and who would be most likely to address them. ${ }^{107}$

For the voter, the KSh1,000 is important, even if it comes only once in five years. Getting it again the next time probably means going ahead and voting for the benefactor. Then there is the expectation that more benefits will accrue when 'our own' is in power; one can hope for access and occasional responsiveness as an individual, or that one's whole region will benefit from more generous government programmes. This mode of patronage is connected to weak levels of responsiveness to citizens as people with specific issues, rather than as tribal voting blocs. 
Some of us, maybe most of us, throw off ethics at election time. Most go after the money. They justify it by saying that receiving the money will not necessarily influence how they vote. But I highly doubt that that is possible. But most people here will tell you that Rachel [the newly elected MP, the first woman to be elected MP in the history of Kitui South] was not elected on the basis of money. People wanted change. They were sick of men's failed leadership over so many years. But we must mobilise people way before election time. Get this person to understand that they must apply for a national $I D$, and register to vote. There are many youth without ID, so they will make noise but they really cannot be part of the change. ${ }^{108}$

The electorate is aware that votes can be a force for change. An MP who apparently did nothing useful was voted out in Kitui and replaced by one in whom the voters have more confidence. They base their faith on a few signs of change, such as the convening of public meetings at grassroots level to identify bursary beneficiaries. But even her supporters admit that it is early days yet. There have been experiences of dashed hopes before, as the politician is swept away into a system that demands that she acts and speaks differently than she did before her election.

We can trust "Mama" Rachel. She can do a lot. I think we can count on her. She did a lot to help the families of the four men who died in a well. She brought in the Red Cross. At the funeral she talked a lot about the water problem, so I know she will work hard. $^{109}$

When asked specifically which institutions/offices they view as believable or worth counting on to solve the food problem, the slide away from institutions and towards individual politicians was obvious. There is a touch of irony to people's rueful reflections on the electoral game: 'I was 100 per cent sure that food prices would fall [once my political candidate was in office],' said a community activist in Mathare. Another echoed this by saying:

When I was voting, I knew that there would be change; food costs would go down, the youth would get jobs, but now all those people campaigning were very intelligent, they knew if they said that food would become affordable, we would vote for them. So I voted knowing that not all of them would deliver, so I picked the one that I most closely identified with.

A third added:

Before I voted, I tried to go to rallies to listen and whenever I got the chance, I would raise my hand to ask them about the cost of food and they would immediately answer that they would lower the cost of food. I had hope because if we could help lower the cost of food, we can join as a community and help bring change.

A self-help group member in Ikutha said:

It's just like the boy who comes courting your daughter. When asked, he says he will take care of your girl. Some years down the line, the girl wishes she never married. The same here; the ones we voted for just honk their horns at us when we try to stop them on the road. There is a councillor we have now nicknamed "Councillor peep!" That is all you hear; he will hoot on his motorbike and wave as he rides past without stopping. 
None of the handshakes we got during the campaign. So we did not re-elect him this last round of elections. They only go to fight for their own salaries.

One Ikutha ironist added - 'But mind you, if they were to come here now, we would dance for them.' The picture is one of following unspoken rules on how one should relate to the political class, performing to a script tacitly authored decades ago.

\section{Conclusion}

Despite having the right to food in its constitution, factors rooted in Kenya's history and political economy have dampened citizen expectations of the state, translating into a weak moral economy around food and lethargy around popular mobilisation, and contributing to a persistent and predictable failure of accountability for hunger. This failure is evident both in the short-term measures employed by the authorities in response to the food price surges of 2009 and 2011, and in long-term policy measures that affect food directly or indirectly.

The short-term measures were - even from internal assessments - short-lived, poorly targeted and poorly coordinated, driven by momentary political anxiety. They are a textbook study in absence of accountability: no clarity on which institution had overall responsibility; no identifiable targets or standards against which performance may be assessed; no criteria for identifying beneficiaries and preventing leakage or diversion; no sanction on officials for failure; no remedies for those aggrieved; no procedure for seeking redress; and no participation in the design or monitoring by those affected.

An assessment of the long-term policy measures yields a mixed picture, but overall it is one that suggests that policymaking is not driven by the pursuit of accountability for affordable and good quality food for all. Staple food prices remain stubbornly high. Intervention in maize marketing through the NCPB, very high import duty on grain from outside the East African Community, non-tariff barriers to regional cross-border trade in grain, and the emphasis on fertiliser in production subsidy programmes favour the maize-surplus areas. These policy measures benefit large traders and no more than 3 per cent of farmers who account for more than 50 per cent of the total domestic maize production.

An overlap of economic and political power brings a peculiar sharpness to the challenge of re-orienting policy: the maize surplus areas happen to be two vote-rich regions, and the large-scale farmers are either politicians or politically well-connected. The National Food and Nutrition Security Policy indirectly acknowledges these problems by calling for more predictable and transparent state involvement in markets, but it does little to chart a way forward on these widely discussed and seldom legislated-for problems. In social protection a proposed shift from food aid to cash transfers promises to seal loopholes for manipulation and corruption by local administrators, but the measures cover only a tiny proportion of the immense need, and the pockets of good practice in accountability, such as the Hunger Safety Nets Programme are yet to permeate the broader system. In short, government is held to account not for a moral economy, but for an unequal economy. Powerful brokers are pushing a growth agenda with an argument that ultimately the benefits may trickle down to people on low incomes. The objective result in terms of persistent hunger is stark. Is it set to remain so?

Whereas there certainly are individual officials and politicians whose responsiveness accounts for the isolated positive incidences, this alone is not sufficient to engineer a shift in policy direction toward institutional accountability. It needs to be bolstered by the sustained pressure of popular mobilisation. Yet popular mobilisation around food on the national stage is only emergent and has tended to be episodic. For ordinary citizens, accountability from the governing class is more a matter of folklore than experience, so it is hardly surprising that 
expectations are low. Civil society activism, existing within the same political economy, has had to do battle with citizen inertia and media's tendency to dazzle rather than question too deeply. So far it has failed to sustain anything like the outrage required to generate a movement that could shift the political economy towards a moral economy.

Popular mobilisation needs to cohere into a movement that can sustain collective action until gains are consolidated. The work of Bunge la Mwananchi has taken steps in this direction, using the 2010 constitution to mould a rights consciousness within Kenyan public discourse. However, this needs to be grown and sustained to a scale comparable to India's Right to Food campaign which after 14 years or so can finally boast a Food Security Act and numerous court-ordered government programmes benefiting millions of poor citizens. Only such movement-building, combined with strategic and informed engagement with responsive individuals within government, is capable of driving food policy towards accountability to the majority of Kenyans - and away from the perpetuation of the inherited privilege of a few large-scale producers and traders. 


\section{Annex 1 Government officials and activists interviewed}

Government officials:

- A member of parliament

- A senior official of the National Drought Management Authority

- A senior official of the Social Protection Secretariat

- A senior official in the Ministry of Agriculture's Food Security and Early Warning (under which the Strategic Grain Reserve falls)

- A senior official in Relief and Rehabilitation in the Directorate of Special Programmes (under which the national food aid distribution programme falls)

- A technical adviser to the Hunger Safety Nets Programme

- A senior official of the policy department of the Kenyan Revenue Authority

- A former senior official of the Kenyan Revenue Authority

- Chief, Mathare location

- $\quad$ Chief, Simisi location, Ikutha

- An elected county representative from one of the outlying areas of Ikutha

Activists:

- The president of Bunge la Mwananchi

- A senior adviser in the National Taxpayers' Association

- A former activist against corruption in the food aid sector

- A tax justice campaigner 


\section{Annex 2 Clustering of participants in focus group discussions}

Ikutha site:

- Cereals and retail traders based in Ikutha market

- Sellers of low-value commodities on market day (porridge, ropes; exclusively women)

- Cereals, vegetables and retail traders based in smaller outlying market centres

- Farmers' groups

- Recipients of food aid and 'food for work' programmes

- Charcoal burners

- Assortment of community self-help groups in one of the outlying areas (Simisi).

Mathare site:

- Community activists

- Butchers and kiosk operators

- 'Dhobi' women (who work for a daily wage doing laundry in neighbouring Eastleigh)

- Internally displaced persons (since the post-election violence of 2007, dependent on intermittent distribution of food aid)

- Roadside sellers of cooked food

- Vegetable sellers (very small scale)

- Youth 


\section{References}

Anyanzwa, J. and Kamau, M. (2013) 'Tax Shocker in Cabinet Secretary Henry Rotich's Budget in his Bid to Fund New Rail System', EA Standard, 15 June, www.standardmedia.co.ke/?articleID=2000086001\&story title=tax-shocker-in-cabinetsecretary-henry-rotich-s-budget-in-his-bid-to-fund-new-rail-system\&pageNo=1 (accessed 18 June 2015)

Ariga, J. and Jayne, T.S. (2010) 'Maize Trade and Marketing Policy Interventions in Kenya', in Food Security in Africa: Market and Trade Policy for Staple Grains in Eastern and Southern Africa, Rome: FAO

Ariga, J.; Jayne, T.S. and Njukia, S. (2010) 'Staple Food Prices in Kenya', paper prepared for the COMESA Policy Seminar, Variation in Staple Food Prices: Causes, Consequence and Policy Options, Maputo, Mozambique, COMESA, MSU, IFPRI

Barasa, L. (2009) 'The Day Kenya Workers' Anger Boiled Over', Daily Nation, 1 May, www.nation.co.ke/News/-/1056/593070/-/u6683d/-/index.html (accessed 18 June 2015)

Barasa, L. and Mwaniki, M. (2011) 'Kalonzo Urges Patience Over Cost of Living', Daily Nation, 19 April

Berman, B.; Cottrel, J. and Ghai, Y. (2011) 'Patrons, Clients and Constitutions: Ethnic Politics and Political Reform in Kenya', Canadian Journal of African Studies 43.3: 462-506

Chambers, R. (2012) Provocations for Development, Rugby: Practical Action Publishing

Chambers, S. (2002) 'A Critical Theory of Civil Society', in S. Chambers and W. Kymlicka (eds), Alternative Conceptions of Civil Society, Princeton: Princeton University Press

Daily Nation (2013) 'Lobby Protests at Bid to Increase Food Prices', 7 July, www.nation.co.ke/News/Lobby-protests-at-bid-to-increase-food-prices/11056/1907958/-/wrtia4/-/index.html (accessed 18 June 2015)

Daily Nation (2013) 'Protests, Strike Threats, Greet Uhuru Budget', 14 June

Daily Nation (2013) 'Consumer Lobby Opposes Move to Reintroduce VAT Bill', 12 June

Daily Nation (2011) 'Consumer Federation Chief Warned Over Food Protests', 25 April, www.nation.co.ke/news/-/1056/1150446/-/lx233r/-/index.html (accessed 18 June 2015)

Daily Nation (2011) 'MPs Lost a Golden Chance to Show Solidarity with Hungry Kenyans', 20 April, www.nation.co.ke/oped/Letters/-/440806/1148162/-/9tegc6/-/index.html (accessed 18 June 2015)

Daily Nation (2011) 'Kibaki Pledges Action on Food Prices', 21 April, www.nation.co.ke/news/Kibaki-pledges-action-on-food-prices/-/1056/1148994/Imfgfus/-/index.html (accessed 18 June 2015)

Daily Nation (2011) 'Kalonzo Urges Patience Over Cost of Living', 19 April, www.nation.co.ke/News/-/1056/1147378/-/10ycd5iz/-/index.html (accessed 18 June 2015) 
Daily Nation (2011) 'Don't Expect Endless Patience as Prices Soar', 16 April, www.nation.co.ke/oped/Editorial/Dont-expect-endless-patience-as-prices-soar-//440804/1145824/-/1feih7z/-/index.html (accessed 18 June 2015)

Demombynes, G. and Kiringai, J. (2011) The Drought and Food Crisis in the Horn of Africa, Impacts and Proposed Policy Responses for Kenya, Nairobi: World Bank Poverty Reduction and Economic Management Unit, Africa Region

Druilhe, Z. and Barreiro-Hurlé, J. (2012) Fertilizer Subsidies in Sub-Saharan Africa, ESA Working Paper No.12-04, Rome: FAO

Fengler, W. and Kiringai, J. (2010) 'Running on One Engine: Kenya's Uneven Economic Performance with a Special Focus on the Port of Mombasa - Kenya Economic Report', Kenya Economic Update, edition no. 2. Washington DC: World Bank. http://documents.worldbank.org/curated/en/2010/06/12384899/running-one-enginekenyas-uneven-economic-performance-special-focus-port-mombasa

Fengler, W. and Kiringai, J. (2009) 'Still Standing: Kenya's Slow Recovery from a Quadruple Shock with a Special Focus on the Food Crisis - Kenya Economic Report', Kenya Economic Update, edition no. 1. Washington DC: World Bank. http://documents.worldbank.org/curated/en/2009/12/12384893/still-standing-kenyasslow-recovery-quadruple-shock-special-focus-food-crisis

Food and Agriculture Organisation (FAO) (2014) Global Information and Early Warning System (GIEWS). Available online at http://www.fao.org/giews/pricetool/ (accessed 29 June 2015)

Food and Agriculture Organisation (FAO) (2013a) Economic and Social Development Statistics Division, www.foodsecurityportal.org/api/countries/world-maize-price (accessed 17 June 2015)

Food and Agriculture Organisation (FAO) (2013b) FAOSTAT Online Statistical Service. Rome: FAO. Available online at: www.fao.org/economic/ess/ess-fs/ess-fadata/en/ (accessed 29 June 2015)

Fowler, A. (1991) 'The Role of NGOs in Changing State-Society Relations: Perspectives from Eastern and Southern Africa', Development Policy Review 9: 53-84

Gatimu, C.W. (2014) Life in a Time of Food Price Volatility: Evidence from the Poor and Vulnerable in Mukuru and Lango Baya, Kenya, Brighton: IDS and Oxfam GB

Gitonga, A. (2012) 'MPs Warn of Food Riots Over VAT Hike', EA Standard, 27 July. www.standardmedia.co.ke/?articleID=2000062763\&story title=MPs-warn-of-food-riotsover-tax (accessed 18 June 2015)

Goetz, A.M. and Jenkins, R. (2005) Reinventing Accountability: Making Democracy Work for Human Development, New York: Palgrave Macmillan

Gross, A.; Mohite, R. and Rutten, L. (n.d.) Impact Assessment of Alternative Approaches to Mitigating Trade Related Risk Exposure in ESA Grain Markets (Maize), (commissioned by Trade and Markets Division, FAO)

Höffler, H. and Ochieng, B.W.O. (2009) High Commodity Prices - Who Gets the Money? A Case Study on the Impact of High Food and Factor Prices on Kenyan Farmers, Germany: Heinrich-Boell-Foundation 
Hossain, N. and Green, D. (2011) Living on a Spike: How is the 2011 Food Price Crisis Affecting Poor People?, Brighton: IDS and Oxfam GB

Hunt, A. (1990) 'Rights and Social Movements: Counter-Hegemonic Strategies', Journal of Law and Society 17: 309

Jayne, T.S. (2012) 'Managing Food Price Instability in East and Southern Africa', Global Food Security 1.2: 143-49, www.sciencedirect.com/science/article/pii/S221191241200017X

Jayne T.S. and Tschirley, D. (2010) 'Food Price Spikes and Strategic Interactions between the Public and Private Sectors: Market Failures or Governance Failures?', Commodity Market Review 2009-2010

Jayne, T.S.; Myers, R.J. and Nyoro, J. (2008) 'The Effects of NCPB Marketing Policies on Maize Market Prices in Kenya', Agricultural Economics 38.3: 313-25

Kanyinga, K. (2004) 'Civil Society Formations in Kenya: A Growing Role in Development and Democracy', in D. Okello (ed.), Civil Society in the Third Republic, Nairobi: National Council of NGOs

Karingi, S.N. and Wanjala, B. (2005) 'The Tax Reform Experience of Kenya', Research Paper No.2005/67, New York: UNU-WIDER

Kenya Food Security Steering Group (KFSSG) (2010) The 2010 Long Rains Season Assessment Report www.disasterriskreduction.net/fileadmin/user upload/drought/docs/2010\%20SRA\%20 Report Final\%20Draft\%281\%29.pdf

Kiringai, J. and Fengler, W. (2011) 'Turning the Tide in Turbulent Times: Making the Most of Kenya's Demographic Change and Rapid Urbanization - Kenya Economic Report', Kenya Economic Update, edition no.4., Washington DC; World Bank http://documents.worldbank.org/curated/en/2011/06/14581745/kenya-economicupdate-turning-tide-turbulent-times-making-most-kenyas-demographic-change-rapidurbanization

Kiringai, J. and Fengler, W. (2010) 'Kenya at the Tipping Point? With a Special Focus on the ICT Revolution and Mobile Money - Kenya Economic Report', Kenya Economic Update, edition no.3., Washington DC: World Bank http://documents.worldbank.org/curated/en/2010/12/13738300/kenya-tipping-pointspecial focus-ict-revolution-mobile-money

Kiringai, J.; Randa, J.; Dihel, N.C.; Mills, I. and Warutere, P. (2012) 'Walking on a Tightrope: Rebalancing Kenya's Economy with a Special Focus on Regional Integration', Kenya Economic Update no.6, Washington DC: World Bank http://documents.worldbank.org/curated/en/2012/06/18481142/walking-tightroperebalancing-kenyas-economy-special-focus-regional-integration

Leys, C. (1975) Underdevelopment in Kenya: The Political Economy of Neo-Colonialism, Berkeley and Los Angeles: University of California Press

Lubaale, G.N. (2013) Life in a Time of Food Price Volatility, Experiences of the Poor and Vulnerable in Mukuru and Langu Baya, Kenya, Brighton: IDS 
Macharia, J. (2013) 'Kenyan MPs Take First Pay Cut, but Allowances Mount,' Reuters, 12 June. www.reuters.com/article/2013/06/12/us-kenya-parliament-payidUSBRE95B0Y220130612 (accessed 18 June 2015)

Maitre d'Hotel E.; le Cotty, T. and Jayne, T.S. (2012) 'Is a Public Regulation of Food Price Volatility Feasible in Africa? An Arch Approach in Kenya', 123rd Seminar, 23-24 February 2012, Dublin, Ireland, European Association of Agricultural Economists

Mamdani, M. (1989) Social Movements and Constitutionalism in the African Context, CBR Working Paper No.2, Kampala: Centre for Basic Research

McCann, J. (1999) 'Maize and Grace: History, Corn and Africa's New Landscapes, 15001999', African Studies Centre Boston University No.223

Minot, N. (2012) Food Price Volatility in Africa: Has it Really Increased? IFPRI discussion papers 1239, Washington: International Food Policy Research Institute (IFPRI)

Minot, N. (2011) Transmission of World Food Price Changes to Markets in Sub-Saharan Africa, IFPRI discussion papers 1059, Washington: International Food Policy Research Institute (IFPRI)

Murphy, S. (2009) Strategic Grain Reserves in an Era of Volatility, Minneapolis: Institute for Agriculture and Trade Policy

Mutambo, A. (2013) 'Activists to Protest Against "Unga" Taxes', Sunday Nation, 16 June. www.nation.co.ke/News/Activists-to-hold-Unga-tax-demo/-/1056/1885152/-/mklhgv/index.html (accessed 18 June 2015)

Mutambo, A. (2011) 'Hunger-driven Drama at Workers' Fete', Daily Nation, 1 May. www.nation.co.ke/News/Hunger-driven-drama-at-workers-fete-/-/1056/1154518/I50p3p0z/-/index.html (accessed 18 June 2015)

Mutambo. A. and Ngirachu, J. (2013) 'Groups Stage Demo Against “Unga” Taxes', Daily Nation, 2 July. www.nation.co.ke/News/-/1056/1902638/-/voa26uz/-/index.html (accessed 18 June 2015)

Mutiga, M. (2011) 'Kenya: World Bank Cancels Funding for Kazi Kwa Vijana Over Graft', Daily Nation, on AllAfrica.com, 22 October. http://allafrica.com/stories/201110240453.html (accessed 18 June 2015)

Njagih, M. (2011) 'Commodity Prices Spark Protests in Kenya', EA Standard, 20 April 2011 www.standardmedia.co.ke/business/article/2000033598/commodity-prices-sparkprotests-in-kenya (accessed 18 June 2015)

Njoroge, K. (2013) 'Groups Set for Rallies Against VAT on Food', Daily Nation, 24 June. www.nation.co.ke/News/Groups-set-for-rallies-against-VAT-on-food/-/1056/1893408/le5qt3ez/-/index.html (accessed 18 June 2015)

Njoroge, K. (2012) 'As Food Prices Rise, Brace Yourself for an Unga War', Daily Nation, 18 June. www.nation.co.ke/Features/DN2/As-food-prices-rise-brace-yourself-for-anUnga-war/-/957860/1886176/-/5k1s1uz/-/index.html (accessed 18 June 2015)

Nyamu-Musembi, C. and Musyoki, S. (2004), Kenyan Civil Society Perspectives on Rights, Rights-based Approaches to Development, and Participation, IDS Working Paper No.236, Brighton: IDS 
Nzuma, J.M. (2013) The Political Economy of Food Price Policy: The Case of Kenya. Working Paper 2013/026, New York: UNU-WIDER

Okello, D. (ed) (2004) Civil Society in the Third Republic, The National Council of NGOs: Nairobi ['Synthesis of the Main Issues Emerging from the NGO Council Conference on "Civil Society in the Third Republic", 15-16 December 2003, Panafric Hotel-Nairobi']

Olick, F. (2013) 'We Will Lower Cost of Food, President Uhuru Kenyatta Assures Kenyans', EA Standard, 21 June www.standardmedia.co.ke/?articleID=2000086431\&story title=Kenya-we-will-lowercost-of-food-uhuru-assures-kenyans. (accessed 18 June 2015)

Opiyo, D. (2011) 'Nairobi Demo Turns Chaotic, 10 people Arrested', Daily Nation, 7 July www.nation.co.ke/News/Nairobi-demo-turns-chaotic-10-people-arrested//1056/1196202/-/ve51d2z/-/index.html (accessed 18 June 2015)

Randa, J. and Gubbins, P. (2013) 'Time to Shift Gears: Accelerating Growth and Poverty Reduction in the New Kenya - Kenya Economic Report', Kenya Economic Update, edition no.8, Washington DC: World Bank http://documents.worldbank.org/curated/en/2013/06/17886043/time-shift-gearsaccelerating-growth-poverty-reduction-new-kenya

Randa, J.; Demombynes, G.; Umutesi, A. and Gubbins, P. (2012) 'Kenya at Work: Energizing the Economy and Creating Jobs.' Kenya Economic Update, edition no.7., Washington DC: World Bank http://documents.worldbank.org/curated/en/2012/12/18481110/kenya-work-energizingeconomy-creating-jobs

Republic of Kenya (2014) Subsidy Fertilizer Distribution Guidelines, Ministry of Agriculture, Livestock, Fisheries, State Department of Agriculture, Nairobi: Government of Republic of Kenya

Republic of Kenya (2013) Budget Statement for the Fiscal Year 2013/2014, Nairobi: Government of Republic of Kenya

Republic of Kenya (2012) Social Protection Sector Review June 2012, Ministry of State for Planning, National Development and Vision, Nairobi: Government of Republic of Kenya

Republic of Kenya (2011a) National Food and Nutrition Security Policy, Agricultural Sector Coordination Unit, Nairobi: Government of Republic of Kenya

Republic of Kenya (2011b) National Social Protection Policy, Ministry of Gender, Children and Social Development, Nairobi: Government of Republic of Kenya

Republic of Kenya (2010) Constitution of Kenya, Nairobi: Government of Republic of Kenya

Republic of Kenya (2007) National Food Security and Nutrition Policy, Sessional paper, Nairobi: Government of Republic of Kenya

Republic of Kenya (n.d.) Food Security District Profile: Kitui District, Eastern Province, Ministry of Agriculture (obtained July 2013)

Ricker-Gilbert, J.; Jayne, T. and Shively, G. (2013) 'Addressing the "Wicked Problem" of Input Subsidy Programs in Africa', Applied Economic Perspectives and Policy 35.2: 322-40. http://aepp.oxfordjournals.org/ (accessed 31 December 2013) 
Shiferaw, B.; Prasanna, B.M.; Hellin, J. and Bänziger, M. (2011) 'Crops that Feed the World 6: Past Successes and Future Challenges to the Role Played by Maize in Global Food Security', Food Security 3: 307-27

Shiundu, A. (2011), 'MPs Protest High Fuel Prices', Daily Nation, 16 November, www.nation.co.ke/News/politics/MPs-protest-high-fuel-prices/-/1064/1273670//6bdndlz/-/index.html (accessed 18 June 2015)

Short, C.; Mulinge, W. and Witwer, M. (2013) Analysis of Incentives and Disincentives for Maize in Kenya. Technical notes series, MAFAP, Rome: FAO

Sinha, D.; Patnaik, B.; Raaj, V.; Bhattacharya, S.; and Joshi, A. (2014) Popular Actions, State Reactions: The Moral and Political Economy of Food in India, Food Riots and Food Rights Project Report, Brighton/New Delhi: IDS

Stammers, N. (1999) 'Social Movements and the Social Construction of Human Rights', Human Rights Quarterly 21.4: 980-1008

Sunday Nation (2013) 'Protests, Strike Threats, Greet Uhuru Budget', 14 June

Think Tank Initiative (n.d.) 'KIPPRA: Debating the Merits of Price Controls', TTI Stories of Influence www.thinktankinitiative.org/sites/default/files/KIPPRA\%20Debating\%20the\%20merits\% 20of\%20price\%20controls.pdf (accessed 18 June 2015)

Thompson, E.P. (1971) 'The Moral Economy of the English Crowd in the Eighteenth Century', Past and Present 50: 76-136

UN Special Rapporteur on the Right to Food (2014) Final Report: The Transformative Potential of the Right to Food, A/HRC/25/57

Van der Walle, N. (2001) 'The Impact of Multiparty Politics in Sub-Saharan Africa', Forum for Development Studies 28.1: 5-42

World Bank (2011) The Drought and Food Crisis in the Horn of Africa: Impacts and Proposed Policy Responses for Kenya, Washington DC: World Bank http://documents.worldbank.org/curated/en/2011/09/15789818/drought-food-crisishorn-africa-impacts-proposed-policy-responses-kenya

World Bank (2009) Still Standing: Kenya's Slow Recovery from a Quadruple Shock (with a Focus on the Food Crisis), Washington DC: World Bank

World Food Programme (2011) Kenya: An Evaluation of WFP's Portfolio 2006-2010, Office of Evaluation, Report Number OE/2011/020. Rome: World Food Programme 